\title{
aquaZone: An Integrative Tool for Sustainable Fish Farm Zoning
}

\author{
Carina Seliger ${ }^{1, * \mathbb{D}}$, Melanie Haslauer ${ }^{1,2}$, Günther Unfer ${ }^{1}$ and Stefan Schmutz ${ }^{1}$ \\ 1 Institute of Hydrobiology and Aquatic Ecosystem Management, \\ University of Natural Resources and Life Sciences Vienna, 1180 Vienna, Austria; \\ melanie.haslauer@lk-noe.at (M.H.); guenther.unfer@boku.ac.at (G.U.); stefan.schmutz@boku.ac.at (S.S.) \\ 2 Lower Austrian Chamber of Agriculture, 3100 St. Pölten, Austria \\ * Correspondence: carina.seliger@boku.ac.at; Tel.: +43-1-47654-81218
}

\section{check for}

updates

Citation: Seliger, C.; Haslauer, M.; Unfer, G.; Schmutz, S. aquaZone: An Integrative Tool for Sustainable Fish Farm Zoning. Sustainability 2021, 13, 1470. https://doi.org/10.3390/su 13031470

Academic Editor: Gioele Capillo

Received: 31 December 2020

Accepted: 25 January 2021

Published: 31 January 2021

Publisher's Note: MDPI stays neutral with regard to jurisdictional claims in published maps and institutional affiliations.

Copyright: (c) 2021 by the authors. Licensee MDPI, Basel, Switzerland. This article is an open access article distributed under the terms and conditions of the Creative Commons Attribution (CC BY) license (https:// creativecommons.org/licenses/by/ $4.0 /)$.

\begin{abstract}
Aquaculture is the fastest-growing animal food production sector and is expected to become increasingly important to meet future food demands. As a landlocked country, Austria's self-sufficiency rate for fish is rather low with $6 \%$ in total and $48 \%$ for freshwater fish. Therefore, and in order to enable sustainable growth of the sector while avoiding negative impacts on the aquatic ecosystem and other uses, we developed aquaZone, a decision support tool for sustainable trout farm zoning. Thereby, 30 spatially explicit criteria related to environmental prerequisites, land use, legal constraints and water quality/quantity were defined, collected and classified according to their suitability for sustainable trout production. Criteria were combined in an integrative GIS-based modelling approach in order to perform the first countrywide and spatially-explicit zonation of suitable areas for aquaculture in Austria. Thereby, 7920 suitable areas with a mean size of 8.2 ha located in 1129 out of 5011 sub-basins (23\%) were identified. The decision tree assigned the highest variable importance to water temperature, slope, agricultural unit, geology, nitrate retention capacity, fish region, minimum flow and pollution risk. These results should support decision making of investors and authorities in order to avoid conflicts and stranded investments at an early stage.
\end{abstract}

Keywords: sustainable aquaculture zoning; freshwater aquaculture; flow-through system; GIS; decision support tool; ecosystem-based management; suitability

\section{Introduction}

On the global perspective, aquaculture is the fastest-growing animal food production sector with an annual growth rate of 5.3\% during the period 2001-2018 [1]. In 2014, farmed fish exceeded wild-caught fish for consumption for the first time [2] and provided 52\% of the demand for human consumption (i.e., $156 \mathrm{Mt}$ ) and $48 \%$ of the global fish production (i.e., $179 \mathrm{Mt}$ ) in 2018 [1]. Bearing in mind that $34.2 \%$ of fish stocks are fished beyond biological sustainability and considering that the demand for fish consumption is expected to increase to $210 \mathrm{Mt}$ by 2050 [3], aquaculture production is expected to become increasingly important [4].

Although there is an ongoing global aquaculture expansion, EU's participation on the producer side is rather low with 1.32 Mt of aquaculture products [5] and a self-sufficiency rate of $42 \%$. In 2018, the European Union (EU-28) was the largest fish-importing market worldwide with an import of $6.34 \mathrm{Mt}$ of fish and aquaculture products $(34 \%$ in terms of value) $[1,5]$. While a few European countries produce more than they consume, Austria only reaches a self-sufficiency rate of $6 \%$ and consumes its last home-produced fish on the 22nd of January and relies entirely on imports for the rest of each year to meet demand. While landlocked countries like Austria will always rely on the import of marine fish, it is, however, surprising that Austria, which is rich in cool freshwater resources ideal for trout production, only achieves a self-sufficiency rate of approximately $48 \%$ for freshwater fish [6,7]. 
In order to support sustainable aquaculture development, strategic tools are required. The call for such approaches already emerged by the late 1980s, when it became obvious that fish resources were all too often recklessly exploited. Starting with the Code of Conduct for Responsible Fisheries (CCRF) [8], sustainable strategies and policies were soon extended also to aquaculture. In 2007, the Ecosystem Approach to Aquaculture (EAA) was initiated to promote the consideration of ecosystem functions and services (including biodiversity), equity for all relevant stakeholders and development in the context of other sectors, policies and goals [9-11]. Following the EU biodiversity strategy [12], the Blue Growth Initiative, which is closely aligned to the Sustainable Development Goals (SDGs), was launched in 2013 [13]. It aims for maximizing economic and social benefits while minimizing environmental degradation and to promote the use of innovative, integrated and multisectoral approaches [14]. Furthermore, the Farm to Fork Strategy (FFS) presented in early 2020 as part of the Green Deal aims at securing a fair, healthy and environmentallyfriendly food system in consideration of climate change effects [15].

The above listed initiatives emphasize the importance of national strategic plans [16]. Especially if aquaculture builds upon public water resources, integrative water resources management and landscape planning is not only essential to enhance productivity, but also to minimize stress on ecosystems $[17,18]$. Furthermore, sound decision-making can only take place under consideration of competing water uses (e.g., hydropower, drinking water, recreation) and conflicting policy goals (e.g., EU Water Framework Directive, Renewable Energy Directive, Floods Directive, Flora-Fauna-Habitat Directive [19-22]). This is also in line with the concept of the water-energy-food nexus [23].

As a result of international and national aquaculture strategies, spatial decision support tools for sustainable aquaculture zoning and site selection are in great demand [24,25]. Thereby, spatial planning can be divided into three steps starting with aquaculture zoning, site selection and aquaculture management areas [14]. Hereby, in terms of freshwater farming, zoning aims for the identification of hydrological systems (e.g., sub-catchments) which are suitable for aquaculture development. In comparison, site selection requires high-resolution input data which are detailed enough to select potential aquaculture sites, while management areas incorporate potential mutual interferences of potential sites and aim for the reduction of risks (e.g., nutrient input or spread of diseases) and utilization of benefits (e.g., production clusters).

Criteria selection depends to a large degree on the production system and species in question. Trout farms rely on their proximity to sufficient, cool, oxygen-rich waters with a stable $\mathrm{pH}$ value. Spatial demands are rather low compared to carp ponds; however, criteria related to environmental prerequisites (e.g., proximity to water sources, slope), water quality (e.g., pollution risk, water temperature) and quantity (e.g., minimum flow) are essential and should be further extended to land use/cover (e.g., sealed surfaces, forest, agriculture), legal constraints (e.g., protected areas, existing and planned uses) and potential risks (e.g., flooding).

Even though required data for spatial planning are nowadays often available in digital form and publicly accessible, their compilation, interpretation and combination for decision-making is challenging. To cope with many different criteria and multiple, potentially conflicting goals, approaches for multi-criteria analysis (MCAs) were introduced around 1970 [26,27]. Since geographic information systems (GIS) can be used efficiently and effectively to explore, analyze, model and combine spatial and temporal aspects of aquaculture on a larger scale, it has been recognized as an important tool for the aquaculture sector $[24,25,28]$. By integrating MCAs in GIS, easily comprehensible output (in the form of maps) can be obtained for increasingly complex spatial management questions [28,29]. Nevertheless, [28] highlights that GIS are often underutilized and their potential is not fully exploited in aquaculture planning.

Despite the fact that spatial planning is indispensable for sustainable development and that aquaculture stakeholders are requesting tools for planning and management of aquaculture facilities [30], no corresponding tool has been developed for trout farming 
in alpine or comparable environments so far. The aim of this paper is therefore (1) to investigate relevant parameters for sustainable aquaculture development, (2) to assess the availability and quality of related spatial data, (3) to develop a conceptual framework and spatially-explicit tool for identifying suitable aquaculture zones and (4) to assess the importance of individual criteria for suitability assessment. Based on Austria's alpine location, the highest absolute growth is envisaged for salmonid species, which is why this study focuses on trout production in flow-through systems utilizing surface water bodies (particularly streams).

\section{Materials and Methods}

\subsection{Study and Investigation Area}

Austria is mostly located in the Alps within the temperate climate zone and covers an area of $83,879 \mathrm{~km}^{2}$ [31]. Due to its central location in Europe, it falls into the transition zone from oceanic (Atlantic) to continental climate, with Mediterranean influences in the south. The different climatic influences and altitudes (i.e., from 114 to $3798 \mathrm{~m}$ ) cause large spatial variations in mean annual precipitation (i.e., from 600 to $1950 \mathrm{~mm}$ ) and mean annual temperatures (from $-9^{\circ} \mathrm{C}$ to $11^{\circ} \mathrm{C}$ ) $[31,32]$. More than half of the mean annual precipitation of $1100 \mathrm{~mm}(\sim 600 \mathrm{~mm})$ is converted into discharge [31,33].

For salmonid fish farms, the proximity to clean, cool and oxygen-rich water is the main prerequisite and therefore crucial for delineating the investigation area. In general, springs, groundwater and surface waters (especially running waters) are utilized for trout farms. Since most farms are located in close proximity to rivers, the national reporting river network (i.e., 32,932 km of rivers with a catchment size larger than $10 \mathrm{~km}^{2}$ and $6713 \mathrm{~km}$ of smaller rivers), was buffered by $250 \mathrm{~m}$ on each side to delineate the investigation area covering $20 \%$ of Austria.

\subsection{Identification of Requirements and Limitations for Trout Production}

Identifying suitable areas requires understanding the main factors responsible for successfully running a trout farm at a specific location. Therefore, we performed a literature review on frequently used criteria for aquaculture operation and siting. While most studies showed a clear focus on environmental criteria, some also incorporated social and economic parameters [34-37].

We grouped relevant criteria for aquaculture siting into the following categories: (1) environmental prerequisites, (2) land use and cover, (3) legal constraints and risks and (4) water quality and quantity (Table 1).

Table 1. Frequently used criteria for aquaculture siting.

\begin{tabular}{|c|c|c|}
\hline Parameter Group & Frequently Used Criteria & References \\
\hline \multirow{6}{*}{$\begin{array}{l}\text { Environmental } \\
\text { prerequisites }\end{array}$} & Proximity to water source & {$[34,36-42]$} \\
\hline & Available area & [38] \\
\hline & Elevation & {$[26,38,43]$} \\
\hline & Slope & {$[34-37,40,43,44]$} \\
\hline & Geology and related criteria (e.g., pH) & {$[34,36,40,45]$} \\
\hline & Special river types (e.g., glacial river) & {$[45,46]$} \\
\hline \multirow{2}{*}{ Land use/cover } & Land use & {$[26,34,36,40-43]$} \\
\hline & Soil characteristics & {$[26,35-37,40,43,44]$} \\
\hline \multirow{3}{*}{$\begin{array}{l}\text { Legal constraints / } \\
\text { risks }\end{array}$} & Protected areas & {$[34,40,43,47]$} \\
\hline & Competing uses & {$[38,40,47]$} \\
\hline & Natural hazards & {$[43,47]$} \\
\hline \multirow{3}{*}{$\begin{array}{l}\text { Water quality/ } \\
\text { quantity }\end{array}$} & Water quality & {$[37,40,43,45,47]$} \\
\hline & Water temperature & {$[34-36,40,45]$} \\
\hline & Water quantity/availability & {$[35,36,43,44]$} \\
\hline
\end{tabular}




\subsection{Criteria Selection and Classification}

Based on the literature review, legal regulations and data availability, we selected a total of 30 criteria for site suitability classification. Most of the data for these criteria were derived from open-access governmental databases or were provided by Austrian ministries and federal states. Criteria were classified into five distinct suitability classes to harmonize types and formats of data (binary, ordinal, metric) and to make them comparable: 0 (no suitability/exclusion), 0.25 (low suitability), 0.5 (medium suitability), 0.75 (high suitability) and 1 (very high suitability; see Table 2). Compared to a fuzzy classification without hard boundaries, the selected classes are more user-friendly concerning the interpretation of results and communication to stakeholders $[37,48]$. After the reviewing process, selected criteria and thresholds were reviewed and if necessary revised by an interdisciplinary panel consisting of practitioners, authorities and scientific institutions.

Table 2. Overview of criteria and their suitability classification (for detailed description see text).

\begin{tabular}{|c|c|c|c|c|c|c|}
\hline & Suitability & $\begin{array}{c}\text { Unsuitable } \\
\text { (0) }\end{array}$ & Low $(0.25)$ & $\begin{array}{l}\text { Medium } \\
\quad(0.5)\end{array}$ & High (0.75) & Very High (1) \\
\hline Category & criteria & & & & & \\
\hline \multirow{2}{*}{$\begin{array}{c}\text { Considered } \\
\text { areas }\end{array}$} & Distance to river ${ }^{1}$ & $>250 \mathrm{~m}$ & & & & $\leq 250 \mathrm{~m}$ \\
\hline & Min. area (ha) ${ }^{2}$ & $<0.4$ & & & & $\geq 0.4$ \\
\hline \multirow{6}{*}{$\begin{array}{l}\text { Environmental } \\
\text { prerequisites }\end{array}$} & Elevation $(\mathrm{m})^{2}$ & $>1000$ & & & & $\leq 1000$ \\
\hline & Slope $(\%)^{2}$ & $>20$ & & $>10-20$ & $>5-10$ & $\leq 5$ \\
\hline & Geology ${ }^{1}$ & & $\begin{array}{l}\text { Bohemian } \\
\text { Massif }\end{array}$ & & $\begin{array}{l}\text { Limestone and } \\
\text { silicate, silicate of } \\
\text { the Central Alps }\end{array}$ & Limestone \\
\hline & Fish region $^{1}$ & Others & & & & Trout region \\
\hline & Lake in-/outflow $^{1}$ & Yes & & & & No \\
\hline & Glacial river $^{1}$ & Yes & & & & No \\
\hline \multirow{4}{*}{ Land use/cover } & Land use ${ }^{3}$ & $\begin{array}{c}\text { Artificial } \\
\text { surfaces, } \\
\text { water } \\
\text { bodies }\end{array}$ & & & & $\begin{array}{l}\text { Agriculture, } \\
\text { grassland and } \\
\text { forests * }\end{array}$ \\
\hline & Agricultural unit 4 & & & & No & Yes \\
\hline & Forest function ${ }^{5}$ & $\begin{array}{c}\text { Protective } \\
\text { (cat. } 2+3), \\
\text { Welfare (cat. } \\
2+3) \text {, Recre- } \\
\text { ational (cat. } \\
\text { 3) }\end{array}$ & & & & $\begin{array}{l}\text { Protective (cat. 1), } \\
\text { welfare (cat. 1), } \\
\text { recreational (cat. } \\
1+2)^{* *} \text {, no forest }\end{array}$ \\
\hline & $\begin{array}{l}\text { Nitrate retention } \\
\text { capacity }^{1}\end{array}$ & & & $\begin{array}{c}\text { Very } \\
\text { low /low, } \\
\text { settlement, } \\
\text { waterbody }\end{array}$ & & $\begin{array}{l}\text { Medium/high, } \\
\text { unknown, forest }\end{array}$ \\
\hline \multirow{4}{*}{$\begin{array}{l}\text { Legal con- } \\
\text { straints/risks }\end{array}$} & Ecological status ${ }^{1}$ & High & & & & Good or worse \\
\hline & $\begin{array}{c}\text { Residual flow } \\
\text { section }^{1}\end{array}$ & Yes & & & & No \\
\hline & Impoundments ${ }^{1}$ & Yes & & & & No \\
\hline & Bathing area ${ }^{1}$ & Yes & & & & No \\
\hline
\end{tabular}


Table 2. Cont.

\begin{tabular}{|c|c|c|c|c|c|c|}
\hline & Suitability & $\begin{array}{l}\text { Unsuitable } \\
\text { (0) }\end{array}$ & Low (0.25) & $\begin{array}{l}\text { Medium } \\
\quad(0.5)\end{array}$ & High (0.75) & Very High (1) \\
\hline & National park ${ }^{6}$ & Yes & & & & No \\
\hline & Nature reserve 6 & Yes & & & & No \\
\hline & N2000 area ${ }^{1,6}$ & $\begin{array}{l}\text { Water- } \\
\text { related }\end{array}$ & & $\begin{array}{l}\text { Not water- } \\
\text { related }\end{array}$ & & No \\
\hline & $\begin{array}{l}\text { Water protection } \\
\text { area } 1,6\end{array}$ & Yes & & & & No \\
\hline & $\begin{array}{l}\text { Valuable river } \\
\text { stretch }^{7-10}\end{array}$ & In conflict & & $\begin{array}{c}\text { With } \\
\text { constraints }\end{array}$ & & $\begin{array}{l}\text { Not in conflict, not } \\
\text { included }\end{array}$ \\
\hline & Flood risk area ${ }^{1}$ & Yes & & & & No \\
\hline \multirow{9}{*}{$\begin{array}{l}\text { Water qual- } \\
\text { ity/quantity }\end{array}$} & $\begin{array}{l}\text { Status of nutrient } \\
\text { pollution }{ }^{1}\end{array}$ & $\begin{array}{l}\text { Moderate or } \\
\text { worse }\end{array}$ & & & & $\begin{array}{l}\text { High/good, } \\
\text { unknown }\end{array}$ \\
\hline & $\begin{array}{l}\text { Status of nat. } \\
\text { pollutants }{ }^{1}\end{array}$ & $\begin{array}{l}\text { Moderate or } \\
\text { worse }\end{array}$ & & & & $\begin{array}{l}\text { High/good, } \\
\text { unknown }\end{array}$ \\
\hline & $\begin{array}{l}\text { Status of EU } \\
\text { pollutants }{ }^{1}\end{array}$ & $\begin{array}{l}\text { Moderate or } \\
\text { worse }\end{array}$ & & & & $\begin{array}{l}\text { High/good, } \\
\text { unknown }\end{array}$ \\
\hline & Pollution risk ${ }^{1}$ & $\begin{array}{l}\text { Potential } \\
\text { risk/risk }\end{array}$ & & & Unknown $* * *$ & No risk \\
\hline & $\underset{1}{\text { Emission discharge }}$ & Yes & & & & No \\
\hline & Contaminated site $^{1}$ & Yes & & & & No \\
\hline & $\begin{array}{l}\text { Water temperature } \\
\text { WTQ }_{95}\left({ }^{\circ} \mathrm{C}\right)^{11}\end{array}$ & $>16$ & & & $12-16$ & $<12$ \\
\hline & $\begin{array}{l}\text { Summer low flow } \\
12\end{array}$ & $\begin{array}{l}\text { July, August } \\
\text { and } \\
\text { September }\end{array}$ & & & & Other months \\
\hline & $\begin{array}{l}\text { Mean annual low } \\
\text { flow } 12\end{array}$ & $<50 \mathrm{~L} / \mathrm{s}$ & & & & $\geq 50 \mathrm{~L} / \mathrm{s}$ \\
\hline
\end{tabular}

${ }^{*}$ Forests are assessed in more detail (criterion "forest function") and were therefore considered suitable here; ** cat. $1=$ low public interest, cat. 2 = medium public interest, cat. 3 = high public interest; *** areas with unknown water quality parameters (i.e., $<10 \mathrm{~km}^{2}$ catchment area) were rated $0.75 ; \mathrm{WTQ}_{95}=95 \%$ quantile of the daily mean water temperature in one year; Data sources: ${ }^{1}$ Ministry of Agriculture, Forestry, Environment and Water Management 2015; ${ }^{2}$ Ministry of Sustainability and Tourism 2018; ${ }^{3}$ Copernicus 2018; ${ }^{4}$ AgrarMarkt Austria 2018; ${ }^{5}$ Federal Forest Office 2018; ${ }^{6}$ Open Governmental Data of Federal States 2018; ${ }^{7}$ Ministry of Agriculture, Forestry, Environment and Water Management 2014 (Federal Law Gazette. II 274/2014); ${ }^{8}$ Regional Government of Upper Austria 2019 (State Law Gazette No. 66/2019); ${ }^{9}$ Regional Government of Styria 2015 (State Law Gazette No. 40/2015); ${ }^{10}$ Regional Government of Lower Austria 2016 (State Law Gazette No. 42/2016); ${ }^{11}$ Borgwardt et al. 2020; ${ }^{12}$ Ministry of Agriculture, Forestry, Environment and Water Management 2007.

\subsubsection{Landscape Criteria}

In a country like Austria, high variation in landscape characteristics predetermines the feasibility of implementing a fish farm at a specific site. With regard to environmental prerequisites, such parameters as elevation, slope, geology, fish region and special river types (i.e., lake in- and outflows and glacial rivers) were evaluated.

Although the potential distribution limit of trout is around 1300 meters above sea level (MASL) [49], such high elevations may be less suitable for aquaculture since they are associated with low production capacities due to low temperatures, long-lasting snow cover as well as undesired icing effects. Therefore, areas above 1000 MASL were considered unsuitable $(\mathrm{S}=0)$.

The slope of the terrain determines whether an area is suitable for placing a fish farm at a specific location. Steep slopes are not suitable but low gradients are ideal to bypass water through fish farm facilities using natural gravity. The slope of an area was calculated from a high-resolution digital elevation model (DEM; $1 \mathrm{~m}$ resolution) by calculating the 
maximum rate of change between each cell and its neighbors using the ArcGIS Spatial Analyst tool "slope". We assigned slopes below 5\% very high suitability $(S=1)$, while areas with $5-10 \%$ and $10-20 \%$ were assigned high and medium suitability, respectively (S = 0.75 and $S=0.5)$. Gradients of more than $20 \%$ were considered unsuitable $(S=0)$.

Geology has a significant influence on water quality parameters, such as $\mathrm{pH}$, alkalinity and hardness. Trout prefer stable $\mathrm{pH}$ values between 5 and 9.5 [50]. Higher shares of calcium carbonate can buffer $\mathrm{pH}$ fluctuations, which is why siliceous soils (e.g., silicate) can be considered less suitable compared to calcareous soils (e.g., limestone). Consequently, we assigned very high suitability $(S=1)$ to limestone, high suitability to mixtures of limestone and silicate and silicate of the Central Alps $(S=0.75)$. The Bohemian Massif (i.e., silicate) was assigned low suitability $(\mathrm{S}=0.25)$.

Following the concept of Illies [51], Austrian rivers have been classified into five main and twelve sub-fish-regions [52]. Ideal environmental conditions for brown trout can be assumed for epi- and metarhithral streams, also known as upper and lower trout region $(S=1)$. Despite the fact that brown trout also inhabits most hyporhithral rivers (i.e., the grayling region), higher temperatures and turbidity as well as increased nutrient loads disqualify those river sections as preferred fish farm sites $(S=0)$.

Glacial rivers as defined by Haßlacher and Langegger [53] represent a special river type [31]. They exhibit high annual and diurnal fluctuations in flow, temperature and turbidity making them rather unsuitable for fish farms $(S=0)$. Further special river types are lake in- and outflows [31]. Lake outflows represent river sections characterized by abiotic, biotic and trophic conditions of the lacustrine ecosystem [54]. High summer and low winter temperature conditions make lake outflows less favorable for aquaculture facilities. Furthermore, fish farms should not be placed at lake inflows as lakes are sensitive to nutrient inputs (eutrophication). In addition, they provide important spawning habitats for some fish species (e.g., Salmo trutta lacustris, Rutilus meidingeri) [55] and substantially contribute to their conservation, which is why they should be protected from any additional impact $(S=0)$ [56]. We considered lake in- and outflows of all lakes $>50$ ha.

The possibility of setting up a new aquaculture facility depends to a large degree on the land cover and use of an area as special types of land use may exclude (e.g., sealed areas), hamper (e.g., forest) or favor (e.g., grassland) fish farm implementation. A comprehensive collection of land cover data is provided by the Coordination of Information on the Environment (CORINE) program, which was implemented as part of the Copernicus Land Monitoring Service initiated by the European Environment Agency. CORINE Land Cover (clc2018) data detect areas with a minimum mapping unit of 25 ha and classify them into 44 land cover categories, which can roughly be grouped into (1) sealed areas (e.g., streets, cities), (2) agriculture, (3) woodland, (4) grassland and (5) water bodies [57]. We only excluded sealed areas and water bodies $(S=0)$ and used additional data for a differentiated assessment of agricultural and woodland areas: in contrast to woodland (i.e., wooded areas), forests are subject to the Austria Forest Law [58] and the Forest Development Plan (FDP) [59]. The FDP provides an important ecological, economic and social basis for forest law decisions and aims for sustainable preservation of guiding functions, which can be differentiated in (a) utilization, (b) protective, (c) welfare and (d) recreational function of high (cat. 3), medium (cat. 2) or low (cat. 1) importance. Forest data were obtained from the Federal Research and Training Center for Forests, Natural Hazards and Landscape [60] and then combined with the nationwide FDP classification. According to legal practice, forests with low protective or welfare function, low to medium recreational function or a mere productive function were attested very high suitability $(S=1)$. On the contrary, the possibility of constructing new aquaculture facilities in forests with medium-to-high protective or welfare function or high recreational function has to be assessed on a caseby-case basis, which is why forests with these features were considered unsuitable $(S=0)$. With regard to agricultural areas, data of the Integrated Administrative and Control System (IACS) [61] comprise a clear delineation of distinct cultivation units according to $\$ 16$ of the Horizontal Regulation of the Common Agricultural Policy [62]. Cultivated land was 
rated with very high suitability $(S=1)$ while uncultivated land was slightly downgraded $(S=0.75)$ to prioritize areas already in agricultural use and to avoid more expensive building grounds. Furthermore, the nitrate retention capacity, which describes the sensitivity of agricultural areas with regard to nitrate discharge based on the Austrian soil mapping [63], was incorporated. Thereby, soils with medium-to-high nitrate retention capacity (including forests) show a lower risk of nitrate pollution and were rated as highly suitable $(S=1)$. On the other hand, soils with low or very low retention capacity (including settlement areas) were downgraded $(S=0.5)$.

In order to define sites with low risks for conflicts and a high probability of approval, the consideration of legal constraints related to existing and planned uses (e.g., hydropower), water and nature protection and flood control is crucial. The EU Water Framework Directive (WFD) [19] and related Austrian laws and directives as the Austrian Water Law [64] and the Quality Objectives Ordinance Ecology (QOOE) [65] clearly stipulate, that all water bodies have to maintain (i.e., no deterioration principle) or reach at least a good ecological status. In order to protect the few remaining water bodies with high ecological status from any additional impact they were excluded $(S=0)$.

Information on existing uses and related impacts (e.g., impoundments, water abstractions) is important to assess potential interference with new aquaculture facilities. Related data are provided by the National River Basin Management Plan [31]. Residual flow sections (i.e., sections impacted by water abstractions) should not be exposed to any additional stress and were, therefore, designated as unsuitable $(S=0)$. Impoundments may feature altered and therefore unsuitable water quality parameters (e.g., water temperature) and show a higher risk of eutrophication once exposed to nutrient-enriched discharges. Therefore, the impoundment itself and an upstream buffer of $500 \mathrm{~m}$ or $1000 \mathrm{~m}$ for impoundments with $50-250 \mathrm{~m}$ or $>250 \mathrm{~m}$ in length were excluded $(S=0)$.

The consideration of protected areas is indispensable for sustainable planning. In national parks, nature conservation has absolute priority $(S=0)$. Furthermore, nature reserves play an important role in Austria, and while existing agricultural and forestry uses are permitted, additional interference with nature must be prevented $(S=0)$. Natura 2000 areas aim to ensure the long-term survival of Europe's most valuable and threatened species and habitats listed under both the Birds Directive (BD; 2009/147/EC) [22] and the Habitats Directive (HD; 92/43/EEC) [20]. In water-related Natura 2000 areas (according to Art. 6 and Annex IV of the WFD) [19], the maintenance or improvement of the status of species and habitats is envisaged. Since aquaculture facilities may interfere with these goals, water-related Natura 2000 areas were considered unsuitable $(S=0)$, while projects in non-water-related Natura 2000 areas require impact assessment and were, therefore, downgraded to medium suitability $(S=0.5)$. A similar principle was applied to provincial laws for protecting valuable river stretches (i.e., $§ 53$ and $\S 55 \mathrm{~g}$ [64]). Areas in clear conflict with the protection goals were excluded $(S=0)$, while areas associated with potential constraints for aquaculture were downgraded $(S=0.5)$. Water protection areas (based on $\S \S 34,35$ and 37 [64]) serve the purpose of ensuring the supply of clean drinking water, which has higher priority than fish production $(S=0)$. With regard to competing uses, we also excluded designated bathing areas including an upstream buffer of 3-5 km (depending on river size; $S=0$ ). Finally, areas with potential significant flood risk (APSFR) based on the risk assessment performed in the frame of the EU Floods Directive (FD) [21] should be avoided in order to prevent potential damage $(S=0)$.

\subsubsection{Water Quality and Quantity Criteria}

In flow-through systems, continuous water flow with high oxygen content and water quality as well as appropriate water temperature ensures the rearing of cold-water fish. Water quality plays a crucial role for aquaculture facilities since pollution by nutrients or contaminants can directly (e.g., by toxic effects) or indirectly (e.g., by reduction of oxygen saturation) affect fish in aquaculture facilities. Several water quality criteria are collected in the frame of the WFD and provide a good basis for water quality assessment. In this 
context, water for aquaculture should be taken only from water bodies with a high or good status related to national and/or EU contaminants and nutrients $(S=1)$. River sections where the risk of pollution via nutrients, national or EU pollutants is unknown were slightly downgraded $(S=0.75)$. River sections in vicinity of industrial or wastewater discharges (i.e., $750 \mathrm{~m}$ downstream of the point source) especially should be avoided $(S=0)$. Landfills classified as "groundwater-relevant" according to the Act on the Remediation of Contaminated Sites [66] were buffered by $1 \mathrm{~km}$ and considered unsuitable $(\mathrm{S}=0)$.

Water temperature is one of the most critical factors for site selection. Adult brown trout, as oligo-stenothermic species, prefer temperatures between $4-19{ }^{\circ} \mathrm{C}$ and may restrict or stop food intake at temperatures outside this range [67]. For reproduction and egg development, low temperatures between $1-9{ }^{\circ} \mathrm{C}$ are considered beneficial $[68,69]$. Concerning oxygen saturation, brown trout require at least $5.5 \mathrm{mg} / \mathrm{L}$, but $>7 \mathrm{mg} / \mathrm{L}$ is preferred, especially at juvenile life stages $[70,71]$. Due to the lack of sufficient water temperature monitoring sites, we used modeled $W Q_{95}$ values as calculated in [72]. WTQ 95 represents the $95 \%$ quantile of the daily mean water temperature in one year and was calculated under consideration of the Strahler order, catchment size, river slope, hill shade, tree cover and the glaciated area in the catchment. We finally used predicted water temperature data for the time period 2021-2050 to allow a buffer for possible temperature increases in the future [72]. According to the preferences of salmonid species, we excluded river sections with a WTQ 95 of more than $16{ }^{\circ} \mathrm{C}(\mathrm{S}=0)$. Furthermore, we considered sections with $\mathrm{WTQ}_{95}<12{ }^{\circ} \mathrm{C}$ ideal $(\mathrm{S}=1)$, while sections with $\mathrm{WTQ}_{95}$ between $12-16{ }^{\circ} \mathrm{C}$ were rated to be of high suitability $(S=0.75)$.

Besides water quality, the persistent availability of water is of utmost importance. While low flow situations during winter are usually less problematic for aquaculture facilities due to low water temperatures, the coincidence of low flow and high temperatures during summer may cause problematic conditions. To take this into account, we assessed modelled hydrologic parameters for more than $5000 \mathrm{sub}$-basins with a mean area of $17 \mathrm{~km}^{2}$ covering the whole area of Austria (e.g., flow distribution) of the digital Hydrologic Atlas Austria (digHAO) [33]. We excluded sites where the lowest mean monthly discharge occurred between July and September $(S=0)$. Furthermore, river sections with a minimum flow, i.e., mean annual low flow (MALF) of less than $50 \mathrm{~L} / \mathrm{s}$, are highly sensitive to water abstractions. Since their suitability has to be assessed on a case-by-case basis, they were excluded $(S=0)$.

\subsection{GIS-Based Data Processing and Identification of Suitable Areas}

All data suitable for nationwide modelling were projected to a homogeneous coordinate system (i.e., MGI Austria Lambert; EPSG 31287) and transferred to a raster format with a resolution of $20 \times 20 \mathrm{~m}$. At this stage, the suitability of each criterion was assessed independently.

In order to gain information on the overall suitability of cells, the suitability values of each criterion (Table 2) were multiplied to calculate the suitability index (SI). Related results are presented per category $\left(S I_{\text {cat }}\right)$ and overall $(S I)$.

$$
S I=\prod S_{i}
$$

Subsequently, suitable neighboring cells were combined to coherent areas, whereby a minimum area of 0.4 ha (i.e., $\geq 10$ cells) had to be reached for further consideration. Smaller areas were excluded from further analyses. Suitable areas were furthermore sub-divided by sub-basin borders and their river affiliation. At river confluences or wherever buffers overlapped, areas were primarily associated to smaller rivers (i.e., based on their total 
length) which are usually more suitable for trout production. Then, mean suitability (MS) was calculated for each independent area.

$$
M S=\frac{\sum S I}{n_{\text {cells }}}
$$

Since one sub-basin often included several potential areas, the highest MS was used for cartographic illustration of the whole sub-basin (i.e., zonal suitability, ZS) and to show the distribution of suitable zones within Austria.

$$
Z S=\max . M S_{\text {zone }}
$$

\subsection{Correlation Analysis and Decision Tree Development}

Based on Spearman's rank correlation, we identified collinearity between criteria in order to remove concerned criteria from further analyses. Then, a regression tree was calculated to identify the most important criteria and their respective influence in the suitability assessment. In order to consider equal samples of all suitability classes, the size of the smallest class was used to randomly select equal samples of all other classes. The resulting data were then split at a ratio of 70:30 into a training and test dataset. The training dataset was used to develop a full tree using the R-package rpart [73] (with a complexity parameter (cp) of 0 and a minimum bucket size of 30) [74]. The tree was pruned by selecting the smallest (i.e., simplest) tree within one standard error of the best tree [74]. The resulting model was then applied to the test dataset to evaluate its performance.

\section{Results}

\subsection{Suitable Areas and Their Distribution}

Based on the applied method, 64,600 ha representing $3.8 \%$ of the investigation area or $0.8 \%$ of Austria are suitable for the establishment of new aquaculture farms. Figure 1 shows the distribution of suitability ratings with log10-transformed cumulative shares and the suitability index from 1 to 0 for a better view of the suitable proportions. With regard to classified suitability ratings, this means that $0.05 \%, 0.98 \%, 1.46 \%$ and $1.31 \%$ of the investigation area was of very high, high, medium and low suitability, respectively.

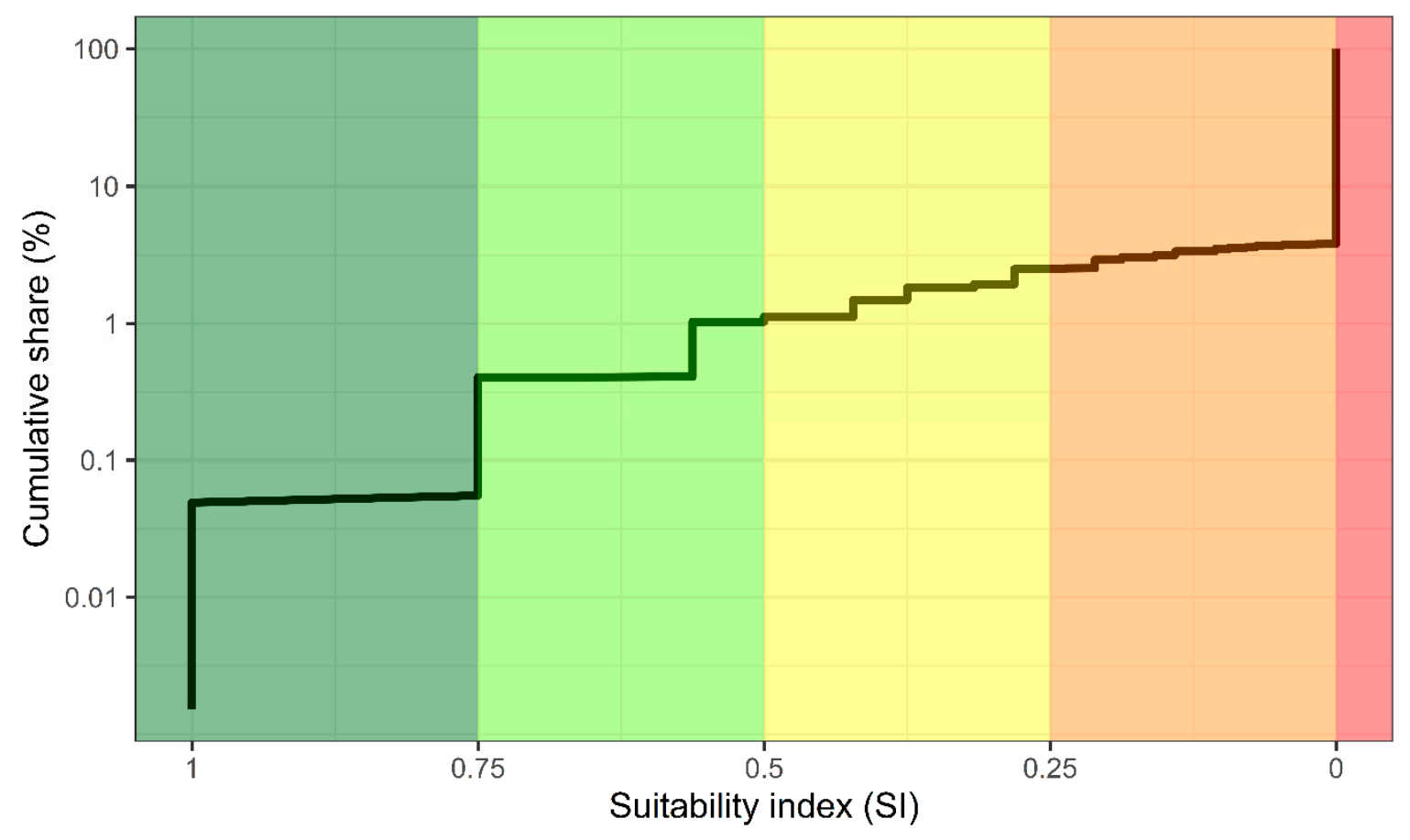

Figure 1. Distribution of suitability ratings. 
The aggregation of coherent suitable cells resulted in 7920 areas within 1129 (i.e., 23\%) out of 5011 sub-basins. Thereby, a sub-basin includes on average seven suitable areas with a mean size of 8.2 ha.

Figure 2 shows the distribution of suitable sub-basins within Austria, whereby 34 (i.e., 3.0\%), 342 (i.e., 30.3\%), 556 (i.e., 49.2\%) and 197 (i.e., 17.5\%) sub-basins include areas of very high, high, medium and low zonal suitability (ZS), respectively. Sub-basins of very high or high suitability are predominantly located at the northern foothills of the Alps.

\section{Suitability}

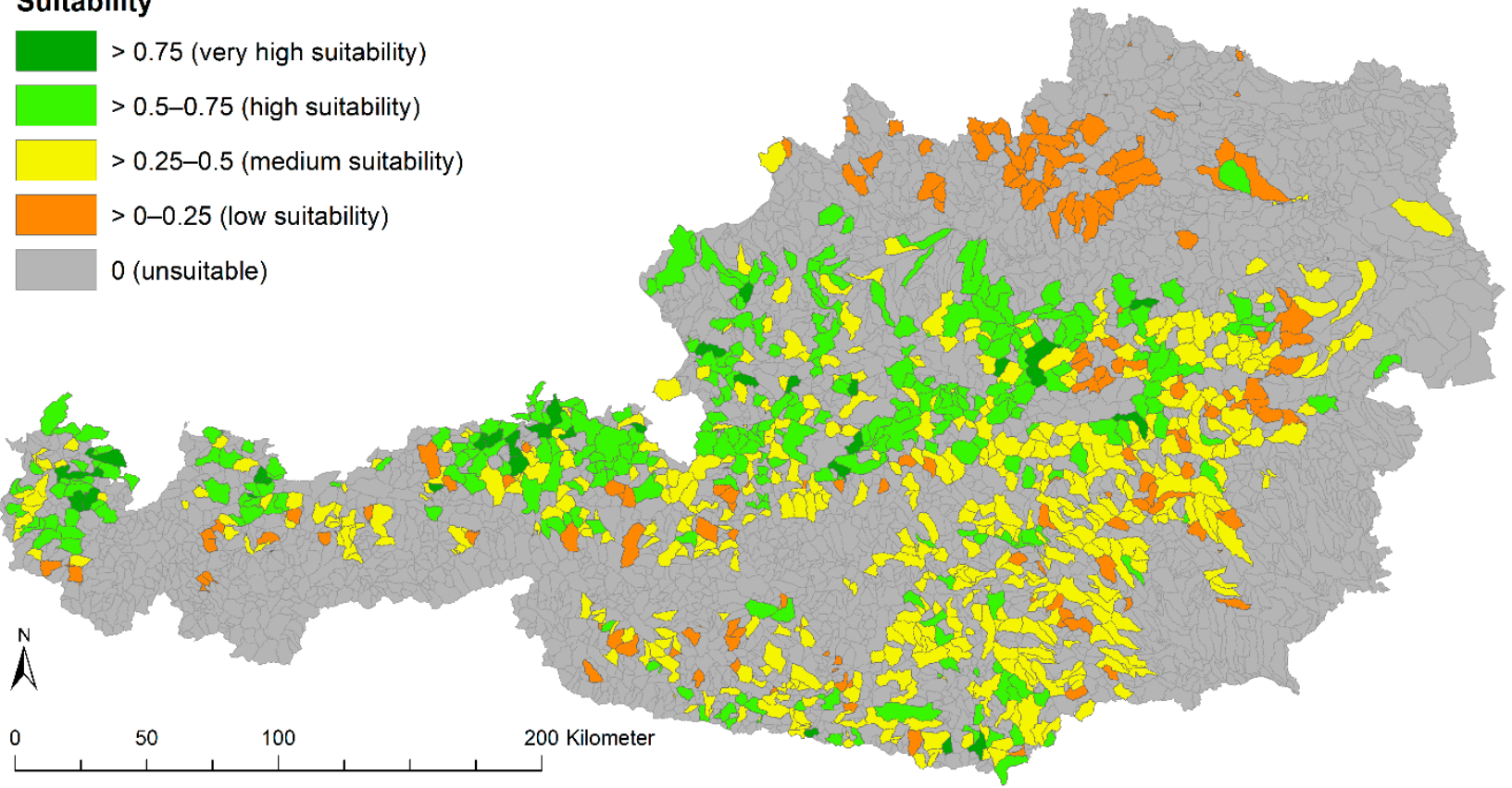

Figure 2. Distribution of suitable zones and their ZS ratings in Austria.

\subsection{Suitability Based on Individual Criteria}

Figure 3 shows the relative suitability of the investigation area for each criterion independently, based on the suitability classification in Table 2. The exclusion rate (i.e., share with no suitability) per criterion ranges from 0 to $48 \%$ with a mean of $10.6 \%$.

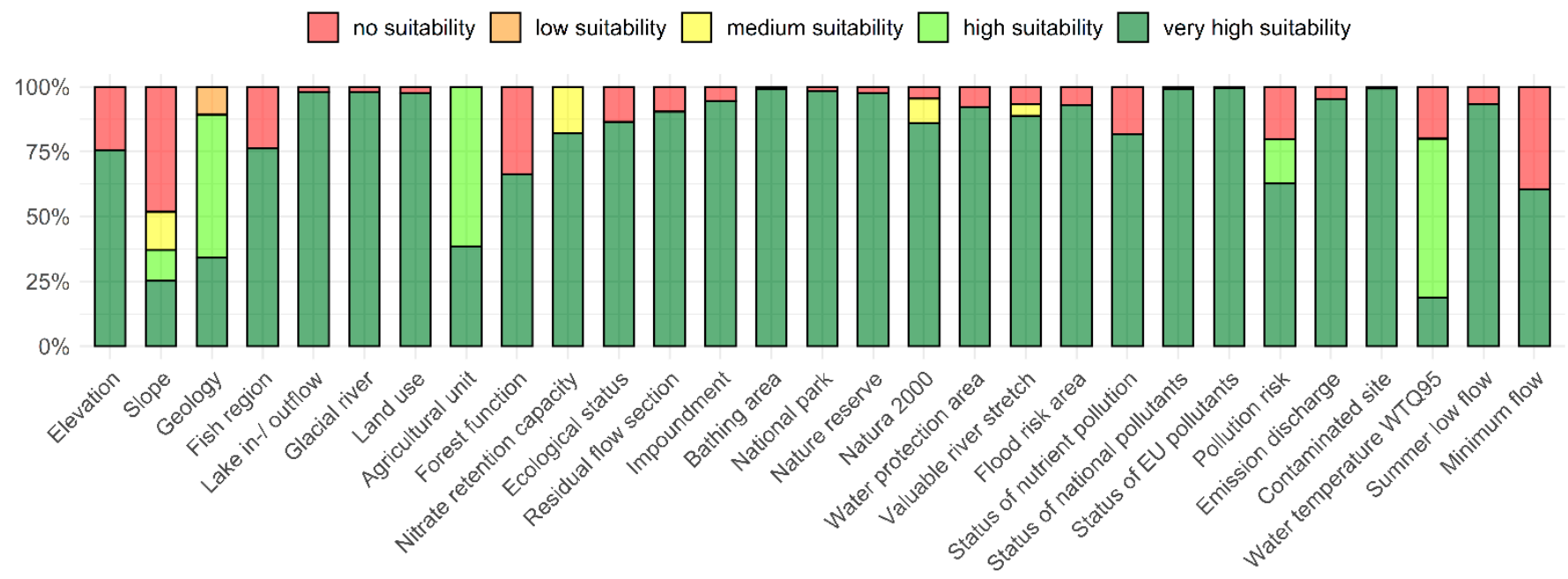

Figure 3. Suitability based on individual criteria. 
About $24.3 \%$ of the investigation area was excluded due to elevations above 1000 MASL. The highest exclusion rate of $48.2 \%$ was caused by slopes $>20 \%$. Moreover, $14.7 \%$ showed medium suitability (i.e., slopes of 10-20\%), 11.7\%-high (i.e., slopes of $5-10 \%$ ) and $25.4 \%$ - very high suitability (i.e., slopes $<5 \%$ ). By definition, no exclusion is caused by geology, but $10.8 \%$ of the investigation area located in the Bohemian Massif is of low suitability, while $55.0 \%$ and $34.3 \%$ of the investigation area obtained high and very high suitability, respectively. About $76.4 \%$ of the investigation area is located in the trout regions and is highly suitable, while $23.6 \%$ located in other fish regions were excluded. Concerning special river types, $2 \%$ of the investigation area is unsuitable because it is located in glacial rivers or lake in- and outflows, respectively.

Only $2.6 \%$ of the investigation area is unsuitable because it represents sealed surfaces or water bodies. $18.0 \%$ of the investigation area was downgraded to medium suitability due to low or very low nitrate retention capacity of the soil, while the remaining $82.0 \%$ shows very high suitability. With regard to agricultural areas, 38.4\% are listed as distinct cultivation units in the IACS and achieve very high suitability. The remaining $61.6 \%$, which were not listed in the IACS, were slightly downgraded to high suitability. $33.6 \%$ of the investigation area are located in unclearable forests (i.e., with high interest in their function) and therefore are not available for aquaculture.

With regard to legal constraints, $13.5 \%$ of the investigation area is unsuitable due to its location along rivers with a high ecological status. Concerning existing uses, $9.6 \%$ and $5.4 \%$ of the investigation area are excluded due to existing water abstractions and impoundments, respectively. Another $0.9 \%$ in the vicinity of bathing areas is also considered unsuitable. Only small proportions are excluded due to protection areas. These are, in particular, $1.7 \%$ of the investigation area located in national parks, $2.4 \%$ in nature reserves and $4.6 \%$ in water-related Natura 2000 areas. Another $9.3 \%$ of the investigation area was set to medium suitability because it is located in other Natura 2000 areas. Furthermore, water protection areas serving the safeguarding of drinking water cause an exclusion of $7.8 \%$. Although valuable river stretches are only designated in some federal states of Austria, they cause an exclusion of $6.8 \%$ of the investigation area. Another $4.4 \%$ may be related to certain constraints (e.g., restrictions for water abstractions) and obtain medium suitability, leaving $88.8 \%$ with very high suitability. About $7.0 \%$ of the investigation area was excluded due to its location in areas with significant potential flood risk.

Concerning water quality, $18.2 \%, 0.7 \%$ and $0.6 \%$ of the investigation area is unsuitable due to nutrient pollution, national and EU pollutants. Furthermore, we considered the risk for pollution via nutrients, national or EU pollutants and thereby excluded $20.2 \%$ of the investigation area. Areas with an unknown risk of pollution were slightly downgraded to high suitability (i.e., 17.0\%). Existing point emissions lead to the exclusion of $4.8 \%$ and another $0.7 \%$ are eliminated due to potential negative impacts caused by contaminated sites. While $20.0 \%$ of the investigation area exceeds the recommended water temperatures during summer, $80.0 \%$ is rated with high (61.1\%) and very high suitability (18.9\%). Finally, summer low flows occurring from July to September make $6.6 \%$ of the investigation area unsuitable and $39.6 \%$ is excluded due to a mean annual low flow below $50 \mathrm{~L} / \mathrm{s}$.

\subsection{Suitability Based on Categories}

Concerning the suitability ratings per category $\left(\mathrm{SI}_{\mathrm{cat}}\right)$, environmental prerequisites caused the highest exclusion rate with $72.8 \%$. The remaining $27.2 \%$ of the investigation area is suitable, whereby $5.9 \%, 6.8 \%, 10.4 \%$ and $4.2 \%$ shows low, medium, high and very high suitability. Concerning land use/cover, $36.0 \%$ of the investigation area was excluded. With $15.2 \%, 20.6 \%$ and $28.3 \%$ of the investigation area with medium, high and very high suitability, respectively, $64.0 \%$ of this area is considered suitable with regard to land use/cover. Concerning legal constraints, $43.8 \%$ of the investigation area was excluded, leaving $49.1 \%, 6.6 \%$ and $0.6 \%$ with very high, medium and low suitability. Finally, $61.2 \%$ of the investigation area was excluded due to water quality/quantity issues, whereas $24.7 \%$ and $14.1 \%$ of this area show high and very high suitability. Concerning the 
overall suitability, $96.0 \%$ of the investigation area is considered unsuitable and only $4.0 \%$ is considered suitable. Because some of the areas designated as suitable do not meet the minimum size criterion (i.e., $>0.4 \mathrm{ha}$ ), the share of suitable areas decreased slightly from $4.0 \%$ to $3.8 \%$ (see Figure 4 ).

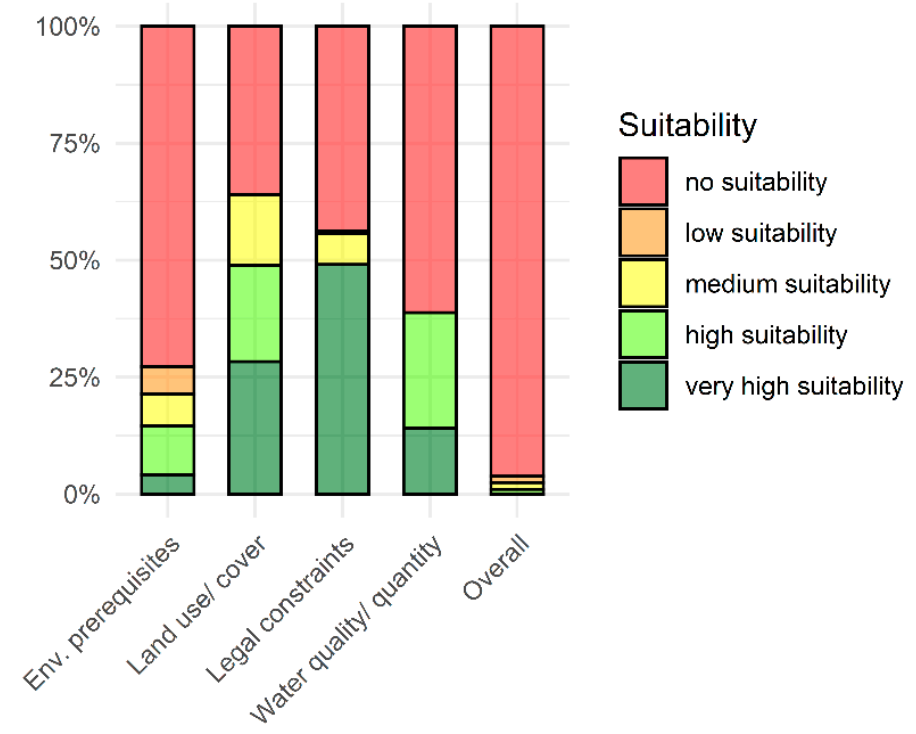

Figure 4. Suitability based on categories and overall.

\subsection{Exclusion Criteria}

A closer look at exclusion criteria $(S=0)$ reveals that $13.8 \%, 19.4 \%, 24.1 \%, 20.7 \%$ and $11.5 \%$ of the investigation area are excluded due to one or combinations of two, three, four and five criteria. The remaining $6.7 \%$ of the investigation area is eliminated based on combinations of six to eleven exclusion criteria (see Figure 5).

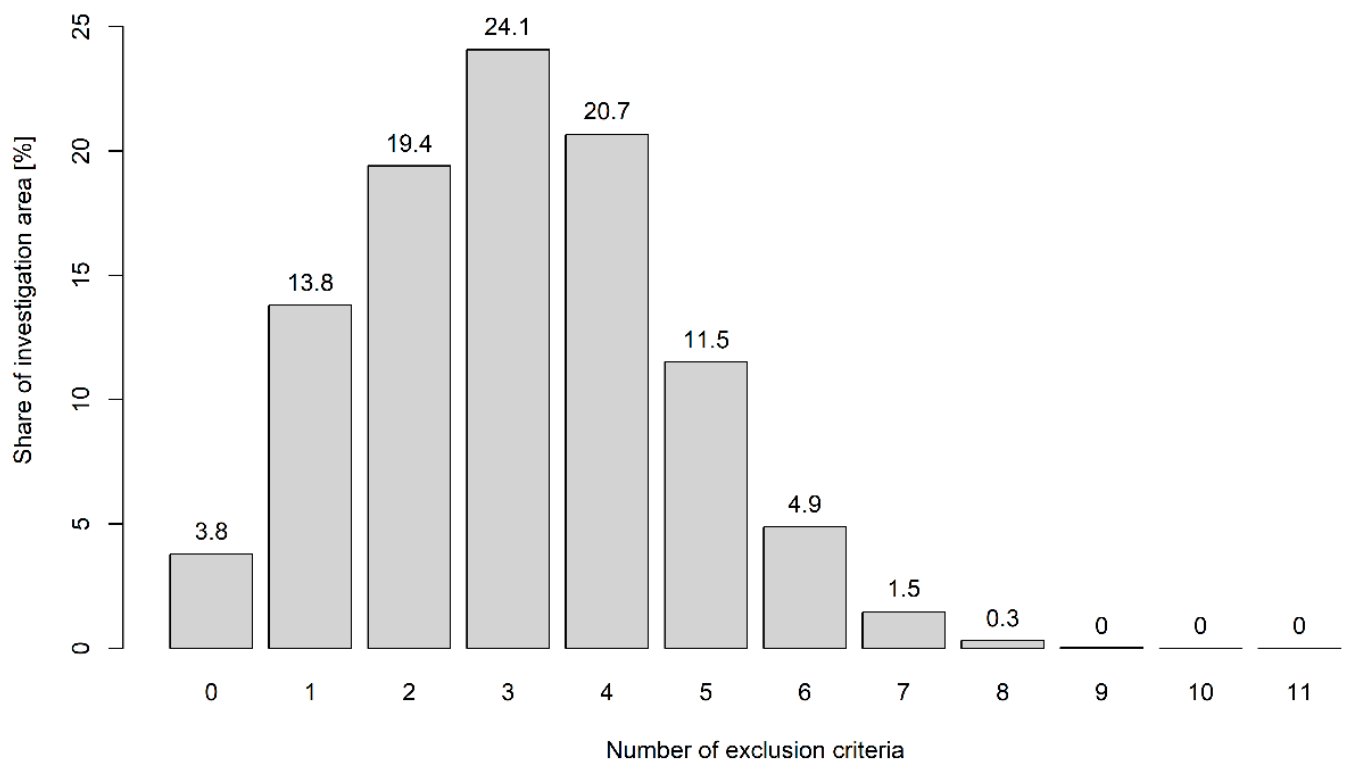

Figure 5. Number of exclusion criteria and their respective exclusion rate.

The assessment of the most frequent exclusion-criteria and their combinations show that the five most frequent reasons for exclusion include the following criteria: minimum flow, slope and forest function (Figure 6). Thereby, 5.6\% of the investigation area is excluded due to the minimum flow criterion, $3.1 \%$-due to a combination of slope and 
forest function criteria, 3.0\%-due to the slope criterion, $2.8 \%$-due to the slope, forest function and minimum flow criteria and another $2.3 \%$-due to the slope and minimum flow criteria.

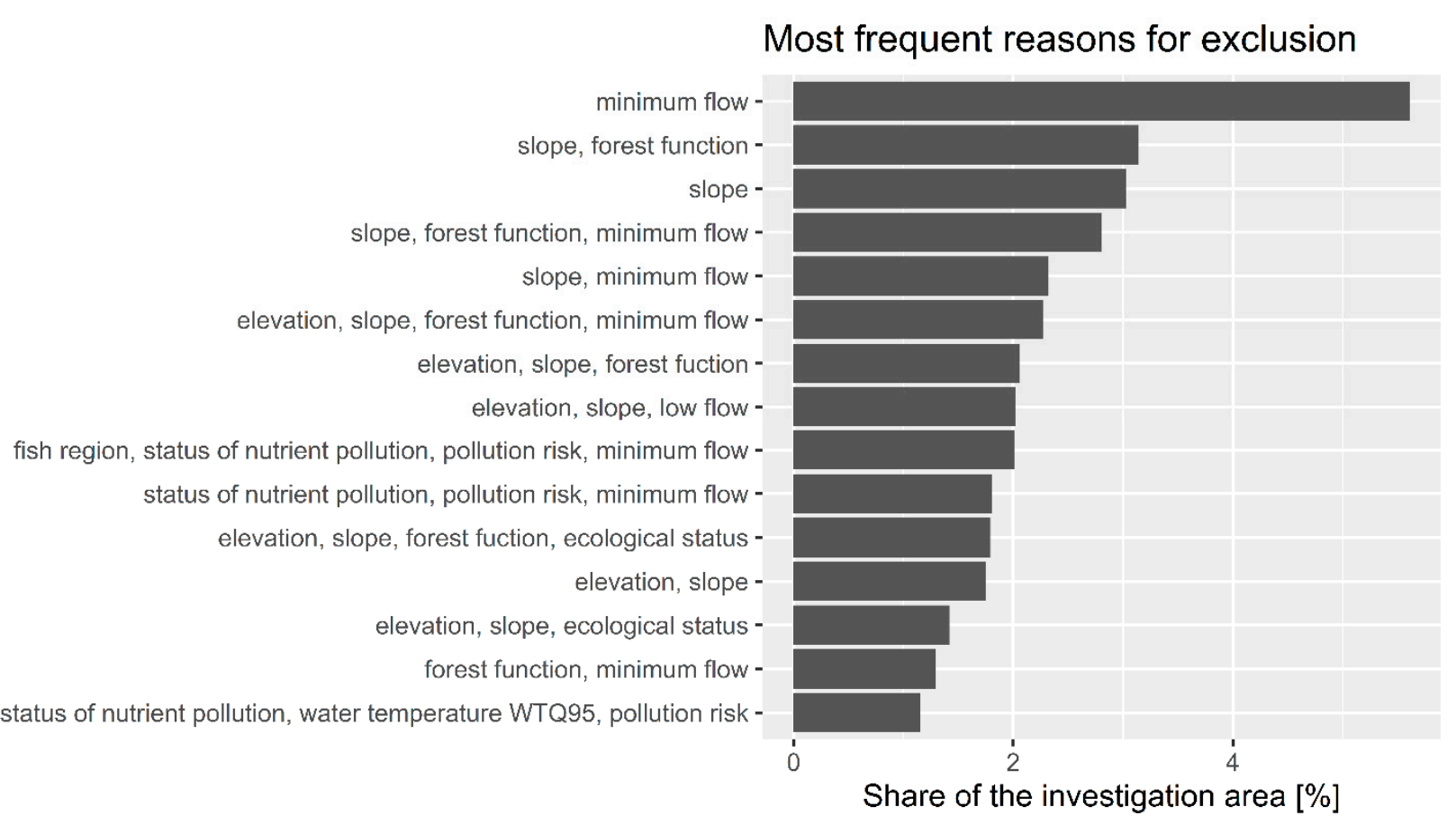

Figure 6. Most frequent reasons for exclusion.

Another $2.3 \%$ of the investigation area is excluded due to a combination of the previously mentioned criteria plus elevation. Elevation in combination with slope and forest function or in combination with slope and minimum flow causes the exclusion of $2.1 \%$ and $2.0 \%$, respectively. Furthermore, $2.0 \%$ of the investigation area is unsuitable based on the fish region, status of nutrient pollution, pollution risk and minimum flow. The remaining six combinations in Figure 6 occur in 1.0 to $2.0 \%$ of the investigation area, while all other combinations are less frequent (i.e., $<1.0 \%$ ).

\subsection{Correlation Analysis}

The Spearman's rank correlation between all the criteria to assess the degree of correlation between individual pairs of criteria was performed with a total sample size of $4,882,593$ areas (representing adjoint homogenous cells). The results indicate that, overall, most correlations are significant $(p$-value $<0.05)$ but low $(\mathrm{rs}<0.4)$, with the exception of a significant strong association between the pollution risk and the status of nutrient pollution ( $\mathrm{rs}=0.78, p<0.001)$, a moderate association between water temperature and fish region ( $\mathrm{rs}=0.59, p<0.001$ ) as well as between bathing areas and lake in-/outflows ( $\mathrm{rs}=0.48$, $p<0.001)$. All other combinations show only a weak $(0.2<\mathrm{rs}<0.4)$ or very weak correlation (rs $<0.2$ ). Based on the results, the criterion "status of national pollutants" was removed from further analyses due to its strong association with the pollution risk. More details are provided in Figure A1 in Appendix A.

\subsection{Decision Tree}

A sample of 8530 homogeneous areas (i.e., 1706 per category) was randomly selected. Based on the training dataset, a pruned tree with 36 final nodes (i.e., 35 splits), a cp value of 0.00042 and a relative error $\left(1-R^{2}\right)$ of 0.14 was developed (explanatory value $R^{2}=0.86$; see Figure S1 in Supplementary Materials). Figure 7 shows variable importance which highlights the importance of the first eight criteria (i.e., with a relative importance $>5 \%$; full tree). The same criteria, namely, (1) water temperature $W_{T Q}$, (2) slope, (3) agricultural 
unit, (4) geology, (5) nitrate retention capacity, (6) fish region, (7) minimum flow and (8) pollution risk were included in the pruned tree.

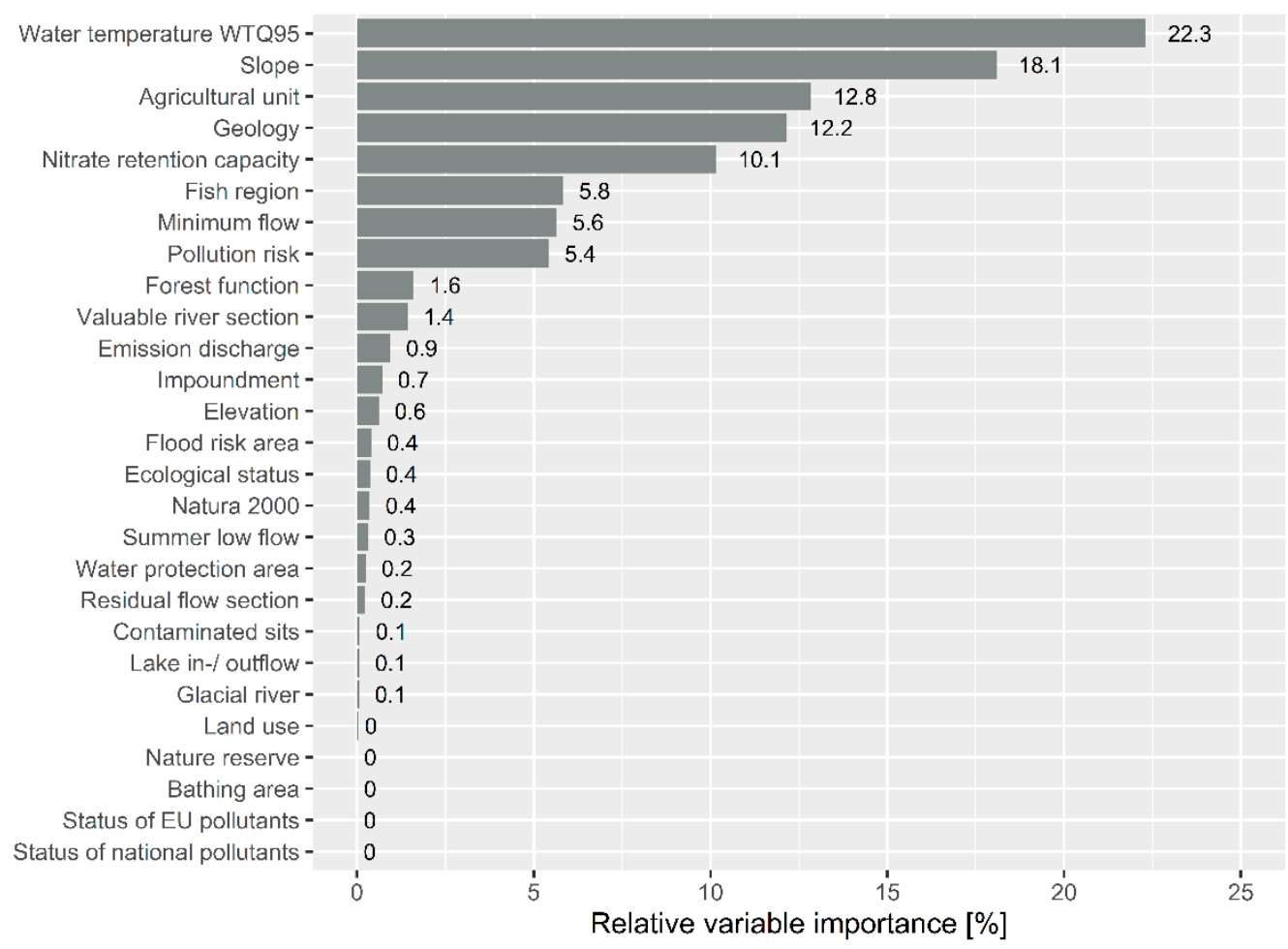

Figure 7. Variable importance of the full decision tree.

Figure 8 shows the changes of $x$-error and $\mathrm{cp}$ with increasing tree size. It highlights that the most significant model improvement occurs until a tree size of five $\left(R^{2}=0.49\right)$ and an explanatory value of $70 \%$ is reached at a tree size of 14 .

The test sample showed a very good performance for high and very high suitability classes (i.e., 0.75 and 1), where all values were predicted correctly (Table 3). Furthermore, with a compliance of $86 \%$ and $83 \%$, good performance for low and medium suitability classes (i.e., 0.25 and 0.5 ) was achieved, respectively. Finally, the prediction of unsuitable areas showed the lowest accuracy (i.e., $70 \%$ ).

Table 3. Predicted versus calculated suitability of the test sample.

\begin{tabular}{cccccccc}
\hline & \multicolumn{7}{c}{ Calculated Suitability } \\
& & $\mathbf{0}$ & $\mathbf{0 . 2 5}$ & $\mathbf{0 . 5}$ & $\mathbf{0 . 7 5}$ & $\mathbf{1}$ & \\
\hline & 0 & 366 & 0 & 0 & 0 & 0 & $366(100 \%)$ \\
Predicted & 0.25 & 50 & 469 & 30 & 0 & 0 & $549(85 \%)$ \\
suitability & 0.5 & 79 & 64 & 421 & 0 & 0 & $564(75 \%)$ \\
& 0.75 & 26 & 12 & 55 & 475 & 0 & $568(84 \%)$ \\
& 1 & 1 & 0 & 3 & 0 & 508 & $512(99 \%)$ \\
\hline & 522 & 545 & 509 & 475 & 508 & \\
& & $(70 \%)$ & $(86 \%)$ & $(83 \%)$ & $(100 \%)$ & $(100 \%)$ & \\
\hline
\end{tabular}




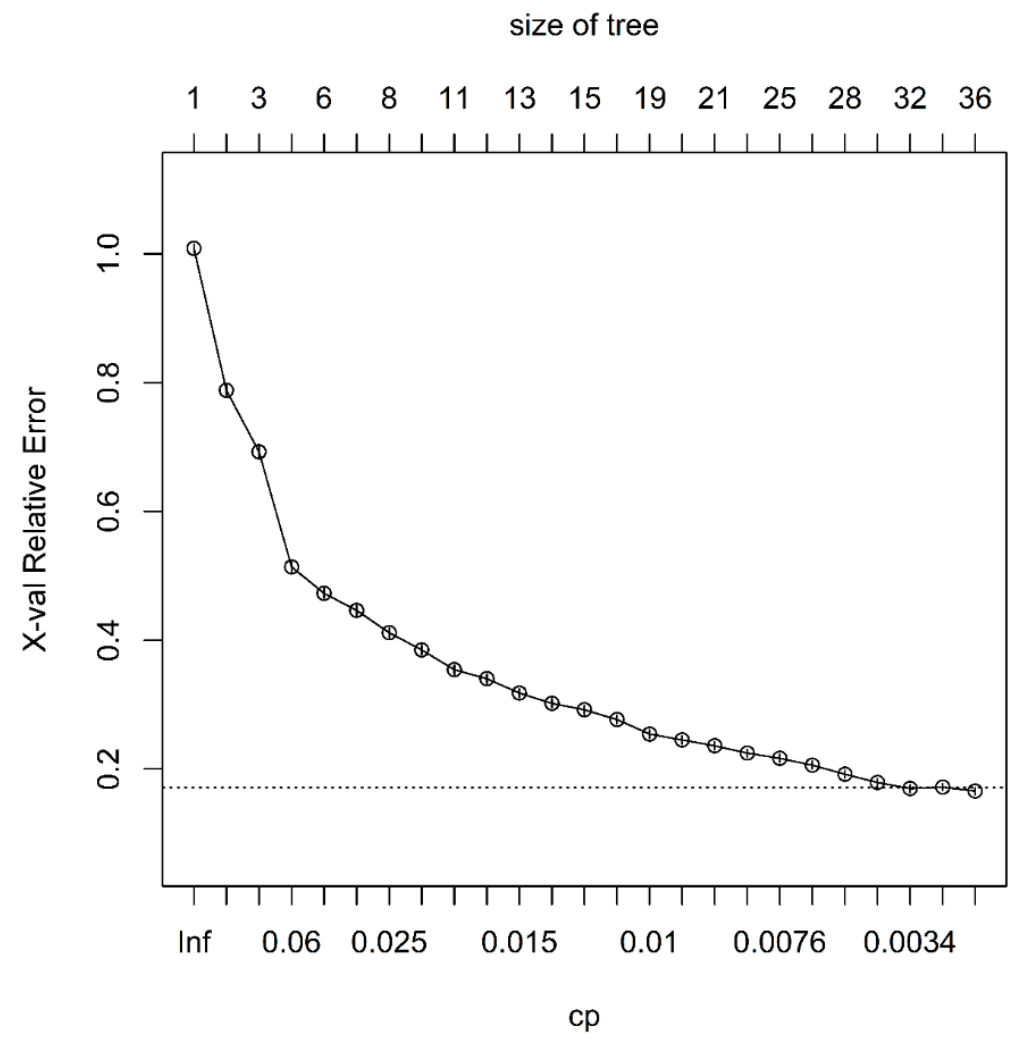

Figure 8. Changes of $x$-error and $c p$ with increasing tree size.

For improved readability, a simplified tree with 14 terminal nodes (T1-14) and an explanatory value of $70 \%$ is presented in Figure 9. Within the tree, each class is represented by one (i.e., very high suitability, $21 \%$ of cases), two (i.e., low suitability, $15 \%$ of cases), three (i.e., high suitability, $26 \%$ of cases) or four terminal nodes (i.e., medium suitability with $26 \%$ and unsuitable areas with $11 \%$ of cases).

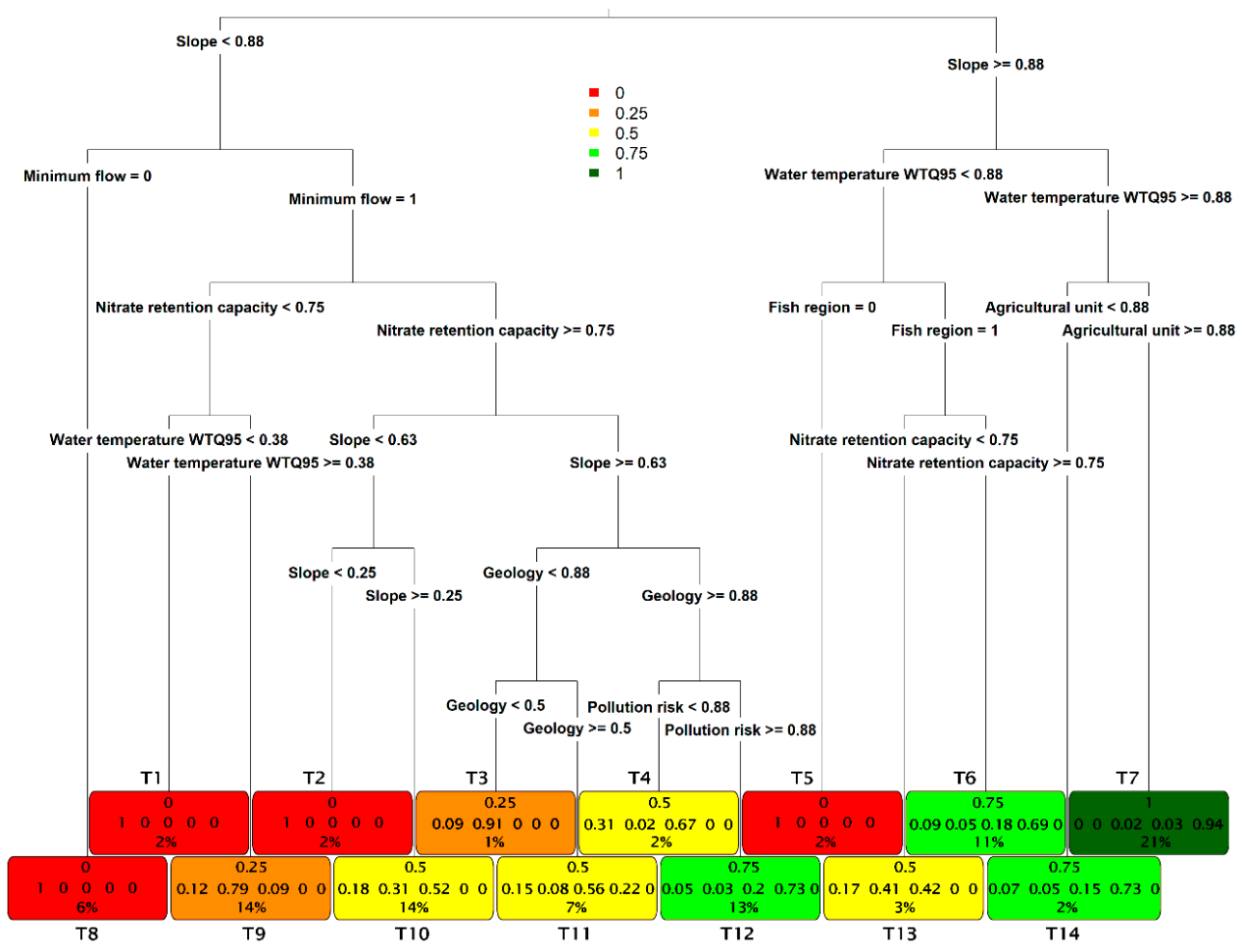

Figure 9. Simplified decision tree. 
The tree is split into two main branches with five and nine terminal nodes each. On the right side of the tree, the classification of very high suitability (T7) is attributed to cases with high suitability concerning slope $(S=1)$, water temperature $(S=1)$ and agricultural unit $(S=1)$. If the area is currently not listed as an agricultural unit, areas are downgraded to high suitability (T14). Cases with a highly suitable slope $(S=1)$, a water temperature rating $\leq 0.75$ and a highly suitable fish region and nitrate retention capacity $(S=1)$ are also attributed high suitability (T6). On the left side of the tree, areas with suitable slopes $(S=0.75)$, minimum flow $(S=1)$, nitrate retention capacity $(S \geq 0.75)$, geology $(S=1)$ and pollution risk $(S=1)$ lead to high suitability $(\mathrm{T} 12)$.

\section{Discussion}

Over the last decades, many guidelines and strategies with regard to sustainable aquaculture development were implemented (e.g., Ecosystem Approach to Aquaculture, Blue Growth Initiative, Farm to Fork Initiative $[9,13,16])$. They encourage states to acknowledge water management as a cross-cutting discipline, which requires integrated, innovative and multisectoral planning approaches. Despite the fact that strategic decision-making tools are in great demand [24,25], they are not yet state-of-the art.

The literature review revealed that aquaculture zoning and siting studies are dominating in marine or coastal environments (e.g., [75-77]). Those for freshwater aquaculture are predominantly performed in developing countries (e.g., [35-37]) with only a few examples in Europe [47]. Most studies focus on regions [36,37,45] rather than entire countries [35,47] or transnational areas $[44,78]$.

Criteria selection is often targeted to reflect specific requirements of distinct species (e.g., tilapia [36], rainbow trout [45] or prawn [40]) and farming systems (e.g., earth ponds $[26,35])$. However, data availability also plays a crucial role for criteria selection [26,34]. Most studies have used 4-25 environmental, economic and social criteria $[34,36,79]$, with a clear dominance of environmental criteria (e.g., [26,38]).

With aquaZone, we have developed an integrative tool for determining suitable zones for sustainable salmonid production in flow-through systems in Austria, which could also represent a potential solution for other countries or regions. Based on literature review and expert judgement, we were able to identify a total of 30 relevant criteria for trout aquaculture in flow-through systems. Even though we only considered environmental factors and neglected socioeconomic ratings, we were able to include more criteria than other studies which focused on salmonid species [34,42,45]. Despite the high number of criteria, the correlation between criteria was only moderate-to-low, with the exception of two criteria with a high correlation (i.e., status of nutrient pollution and pollution risk). Furthermore, to our knowledge, this is the only study considering water quantity criteria (i.e., minimum flow, summer low flow), while other studies only consider water quality or indirect water quantity parameters (e.g., river density, annual precipitation [36]).

While the categories "environmental prerequisites" and "water quality/quantity" may be the most important for assessing the applicability of new fish farms, the categories "land use and cover" and especially "legal constraints and risks" provide insights into the implementability at a specific location.

MCAs as applied in our study have the great advantage that they are broadly used for aquaculture zoning (and other spatial planning instruments), can integrate a multitude of criteria and allow the consideration of different priorities and scenarios [34,37]. While several aquaculture siting studies made use of MCAs in combination with the analytic hierarchy process (AHP) to weigh the importance of criteria $[26,34,39,40]$, we decided to give equal weights to each individual criterion like, e.g., $[38,45]$. We think that this makes the resulting suitability index more transparent and better comprehensible. Furthermore, 23 out of our considered 30 criteria are binary (i.e., suitable or not suitable) and can therefore be considered exclusion criteria, with only the remaining seven criteria responsible for different gradients of suitability. 
With the application of several exclusion criteria, we followed a rather strict approach, which also eliminates areas that are not unsuitable by themselves but rather not recommendable from the point of view of sustainability. Thereby, we focused on highlighting areas with no or minor risk of conflicts. Our results show that the most frequent reasons for exclusion include the following criteria: minimum flow, slope, forest function and elevation, as well as combinations of these criteria. This highlights that steep headwater sections with low MALF and associated with forests of high or medium public interest, which predominantly occur in the Alpine region, may be considered unsuitable. However, areas designated as unsuitable may still turn out to be suitable on the basis of more detailed and individual suitability assessments. Our strict classification with distinct classes has the advantage of easy interpretation, but might exclude areas in transition zones (e.g., slightly above $1000 \mathrm{MASL}$ ). This is especially true for areas with only one exclusion criterion (i.e., $13.8 \%$ of the investigation area). The majority of areas, however, is excluded based on several exclusion criteria (i.e., 82.4\%), which clearly highlights their unsuitability. On the other hand, the feasibility of areas currently rated as suitable depends to a high degree on the ownership structure, willingness for implementation and economic factors, which were neglected in this study.

The decision tree highlighted the relative importance of (1) water temperature, (2) slope, (3) agricultural unit, (4) geology, (5) nitrate retention capacity, (6) fish region, (7) minimum flow and (8) pollution risk. Water temperature is one of the most important factors for trout farms, since it regulates growth and influences oxygen saturation. Furthermore, $[34,80]$ indicate that water temperature is the most important water quality parameter. Our results show that it is moderately associated with fish regions, but shows a slightly higher individual exclusion rate and allows better differentiation between very high and high suitability ratings. Since the expected future water temperature (2021-2050) was used, it additionally excludes areas with a problematic temperature increase, which may not be excluded by the fish region criterion. Furthermore, the designation of fish regions is not widely spread and may therefore not be available in other countries or regions. In certain cases, species distribution models (SDM), such as Biomod [81] and MaxEnt [82], can be used as alternatives [34,37]. Although brown trout also inhabit most hyporhithral rivers, we excluded these sections due to higher temperatures, turbidity and nutrient loads. Since landscape and water criteria were combined in the suitability assessment, sites located at confluences utilizing water from trout regions and bypassing it to receiving grayling rivers cannot be detected by aquaZone. Furthermore, there might be some sections in the transition from trout to grayling region which might also be suitable, but were categorically rejected in our approach. Austria is an alpine country, which also explains why $48 \%$ of the investigation area is rated as unsuitable due to slopes of more than $20 \%$, a criterion also highlighted by $[26,34]$. Under certain conditions and if prepared appropriately (e.g., by terracing), higher slopes could also be suitable. However, this might be associated with higher construction costs and therefore has to be assessed on a case-by-case basis. The agricultural unit criterion does not cause any exclusion but only a slight downgrade of areas which are not listed in the IACS $(S=0.75)$. The high variable importance may stem from the fact that more than $60 \%$ of the investigation area experiences such a downgrade. We think that geology was rated as important since geological features are prevalent at larger scales and might therefore cause the downgrading of whole areas (e.g., areas with less suitability in northern parts of Austria representing the Bohemian Massif). Minimum flow (i.e., a MALF > $50 \mathrm{~L} / \mathrm{s}$ ) has the highest individual exclusion rate (i.e., $6 \%$ ) and is not achieved by $40 \%$ of the investigation area. The abstraction of water from rivers with less MALF may be possible but has to be assessed on a case-by-case basis since these rivers are rather sensitive. Furthermore, water quality is an important parameter for aquaculture facilities. Despite the fact that water quality is generally good in Austria, 20\% of the investigation area show pollution risk which may be decisive for the suitability of an area. In addition, this criterion also reduces the suitability of areas with unknown water quality, which also reinforces its importance. In addition to the previously mentioned criteria, the 
variable importance of nitrate retention capacity may be explained, since this criterion is often responsible for a downgrade by one or two categories.

A comparison of the abovementioned criteria shows that water temperature, slope, agricultural unit and geology rate less than $50 \%$ of the investigation area as highly suitable (see Figure 1), which also explains their relative importance for the suitability assessment. Minimum flow and slope have the highest individual exclusion rate per parameter and are also often included in the most frequent combinations of exclusion criteria (see Figure 6). Despite the fact that the decision tree only includes eight out of 30 criteria, the test sample showed very good performance for high and very high suitability (i.e., 0.75 and 1) and good performance for low and medium suitability classes (i.e., 0.25 and 0.5 ). Only the prediction of unsuitable areas showed a lower accuracy (i.e., 70\%). This highlights that the developed decision tree can be used for predicting zones of (very) high suitability with high confidence.

The remaining parameters may not be included in the decision tree, since they rarely occur in the investigation area (e.g., glacial river, lake in-/outflows, protected areas). However, we still highly recommend their consideration (if related data are available) since they might be the tip on the scale which may ultimately prevent the realization of a planned aquaculture facility. Furthermore, based on their requirements, aquaculture facilities are often located in pristine headwater sections with good ecological status, which become increasingly rare and require special consideration. Freshwaters are already subjected to multiple uses (e.g., aquaculture, hydropower, drinking water, industry and irrigation) and therefore exposed to a variety of pressures (e.g., wastewater discharge, hydromorphological alterations) [83]. Strategic planning with consideration of competing uses and goals is useful for both avoidance and mitigation of impact. Therefore, it plays a crucial role in fulfilling the concept of sustainability, current EU directives and national laws.

As stated by Francisco et al. and Yunis et al. [26,34], the main prerequisite for land suitability assessments is the availability of required spatial data. We think that the data basis in Austria is generally good, thanks to prevailing EU directives (e.g., WFD, FD, BD, HD) and related national regulations and data collections. Therefore, aquaZone might be easily adaptable to other EU countries with similar databases. Criteria selection and rating based on literature review and expert knowledge provided a good basis, where only minor adaptation and additions were necessary in order to improve alignment with stakeholders' experiences and existing aquaculture facilities. The stakeholder involvement was especially proved to be important, not only for reflecting their respective needs, but also for increasing practicability and acceptance of the tool. However, we also have to mention some shortcomings of the available data, which mostly refer to the category "water quality/quantity".

Firstly, within this study, we clearly focused on environmental aspects, neglecting economic (e.g., availability of markets and transport connections, economic efficiency) and social criteria (e.g., landscape scenery, tourism). Yunis et al. [34] concluded that economic and environmental criteria obtain equal weights and are more important than social criteria. Even though we cannot neglect the importance of economic factors, we think that related analyses have to take place on a case-by-case basis since there are several economic factors which are difficult to consider (e.g., property price, production potential). Environmental criteria were selected on the basis of literature review, expert judgment and data availability. However, in any case, the study does not address all potentially important environmental criteria. For instance, the presence of diseases or the potential impact of escaping nonnative species or genetic lineages on endangered and unique endemic genotypes could potentially downgrade sites.

Secondly, we were not able to consider all potential water sources (in particular, groundwater and springs) since there is currently no way to estimate their quantity and utilization intensity in Austria. The application of the minimum flow criterion (i.e., 50\% MALF), may therefore falsely exclude sites with additional water sources. The fact that our approach is currently only applicable to surface water sources is a clear shortcoming. 
However, the examination of a potential effect of groundwater extraction on existing rights is complex and will always require a case-by-case assessment, especially since a quantitative and nationwide assessment is not to be expected in the near future. Furthermore, most springs with significant flow are most likely already exploited, either for aquaculture or other uses. Regardless of the water source, however, proximity to surface waters is indispensable for water discharge. The quantity of surface water bodies was estimated on the basis of the digHAO, which only provides a rough estimation of low flows and their seasonal distribution. Data are only available for sub-basins with a mean catchment size of $17 \mathrm{~km}^{2}$, which is why tributaries with smaller catchments are not well-covered. While the used data seem sufficient for the zoning approach presented here, there is a clear need for more precise data in order to identify suitable sites at finer scales.

Thirdly, the consideration of possible climate change impacts plays a key role in sustainable aquaculture planning. We tried to incorporate this by integrating future water temperatures. However, climate change effects are much more complex and multilayered. Besides temperature, changes to the quantity and seasonal distribution of precipitation and discharge are also essential for aquaculture. Unfortunately, related data currently only exist as rough regional estimates with high fluctuation margins. We, therefore, see a clear need for more detailed data on the expected climate change effects in Austria.

Fourthly, the investigation area had to be selected on the basis of data availability and predominantly includes rivers with a catchment size of $>10 \mathrm{~km}^{2}$. Some researchers $[80,84]$ consider the distance to water sources as most important. However, most streams with a catchment area $<10 \mathrm{~km}^{2}$ had to be excluded from our analyses due to missing data.

Due to the above discussed limitations of some input parameters, it has to be clearly stated that the tool can only provide a zoning for Austria, but it is not suitable for the designation of individual sites. Higher data accuracy could further improve the model output. In any way, a case-by-case assessment of new sites will remain indispensable in order to ensure the compliance with laws.

In this context, we would also like to highlight that obstacles towards sustainable aquaculture development are much broader than the spatial planning considered here and include a multitude of factors [78] which could not be considered here. For instance, for aquaculture to be sustainable, fish feeding must also meet sustainability standards. Fish feeding for carnivorous species held in aquaculture often consist, among others, of fish caught in the oceans. Therefore, it can be concluded that there are many more aspects which need to be considered in order to ensure safer, resilient and sustainable food systems [85] and in order to achieve sustainable development goals.

Yunis et al. [34] summarized seven problems arising from the lack of spatial and administrative planning, which are (i) fish diseases, (ii) environmental problems, (iii) production problems, (iv) social conflicts, (v) post-harvesting problems, (vi) financial risk and (vii) lack of resilience to climate variations and other external threats and disasters. With aquaZone, we want to promote the use of strategic planning instruments for sustainable aquaculture zoning on a larger scale (e.g., national or provincial) in order to avoid these potential problems (in particular ii, iii, vi, and vii). Considering the abundance of geospatial data, a GIS-based and cross-sectoral MCA perfectly suits the idea of sustainability and provides a good basis for the first GIS-based aquaculture zoning tool in Austria. Even if the very strict criteria selection and valuation mean that a comparatively large number of areas is excluded, the results show that Austria has great potential for new sustainable aquaculture operations. Since we only considered surface waters (i.e., rivers and streams) and neglected other water sources (e.g., springs, groundwater), it can be assumed that the actual potential for new aquaculture sites is much higher. In any case, aquaZone shows that strategic planning and prioritization is worthwhile, both from an economic and environmental point of view, and should be considered as state-of-the art.

Once implemented, it can provide a solid basis for decision-making, both for applicants and granting authorities. Applicants may benefit from the provision of processed data and the rapid recognition of unsuitable sites and potential challenges while granting 
authorities can focus on pre-reviewed applications. Furthermore, since obstacles can be recognized at an early stage, the time until approval may be shortened.

\section{Conclusions}

The pursuit of sectoral objectives without consideration of potentially influential or competing uses may lead to suboptimal exploitation of already limited resources and can therefore not be considered sustainable. Since quality and quantity of spatial data continuously increase, combinations of MCAs and GIS are predestined for their assessment and for providing a solid basis for strategic decision-making in water management. While MCA techniques allow the combination of multiple criteria under consideration of different priorities and scenarios, GIS, on the other hand, are a perfect tool for spatial assessment and combination of data as well as the production of easily interpretable maps.

Tools for siting and zoning of aquaculture facilities are especially important for countries which systematically want to increase their production to reach self-sufficiency. Environmental standards in Austria are high, which is a prerequisite for sustainable food systems in order to provide healthy proteins with low ecological footprint. Furthermore, higher levels of self-supply on the EU, national or, ideally, on the regional level do not only reduce dependencies and transport costs, but also outsourcing of impacts to countries with lower environmental standards which again complies with the principle of sustainability. In this sense, the study presented here can support the achievement of these goals.

We think that aquaZone provides a good basis for detecting suitable aquaculture zones which could then be further investigated in detail for the siting of new aquaculture facilities. Furthermore, this study provides a good overview of the most relevant criteria for trout aquaculture in flow-through systems. However, the method could be easily adapted in order to reflect other countries' databases, the requirements of other species (e.g., cyprinids) or modes of operation (e.g., pond, circular).

Supplementary Materials: The following are available online at https://zenodo.org/record/440617 6, Figure S1: Full decision tree of aquaZone.

Author Contributions: Conceptualization, C.S. and M.H.; data curation, C.S. and M.H.; formal analysis, C.S. and M.H.; funding acquisition, S.S.; investigation, C.S. and M.H.; methodology, C.S., M.H., G.U. and S.S.; project administration, C.S. and M.H.; supervision, G.U. and S.S.; visualization, C.S.; writing—original draft, C.S.; writing—review and editing, C.S., M.H., G.U. and S.S. All authors have read and agreed to the published version of the manuscript.

Funding: This research was funded by the European Union through the European Maritime and Fisheries Fund (EMFF) (2014-2020) (F2.4.1-05/18) and by the Austrian Ministry of Sustainability and Tourism.

Institutional Review Board Statement: Not applicable.

Informed Consent Statement: Not applicable.

Data Availability Statement: Restrictions apply to the availability of these data. Data were obtained from the Austrian Ministry of Sustainability and Tourism and federal institutions and are available from the authors with the permission of the concerned authorities.

Acknowledgments: We would like to thank all involved stakeholders for providing their valuable time and expertise. Furthermore, we thank Borgwardt et al. for providing modeled WTQ ${ }_{95}$ data of the project ClimateTrout.

Conflicts of Interest: The funders had no role in the design of the study; in the collection, analyses, or interpretation of data; in the writing of the manuscript, or in the decision to publish the results. 


\section{Appendix A}

\begin{tabular}{|c|c|c|c|c|c|c|c|c|c|c|c|c|c|c|c|c|c|c|c|c|c|c|c|c|c|c|c|c|c|c|}
\hline & \multicolumn{29}{|c|}{ Spearman correlation (upper right part of table) } \\
\hline & & 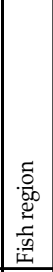 & 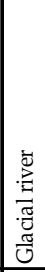 & 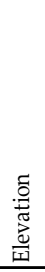 & 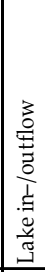 & $\begin{array}{l}60 \\
\frac{60}{8} \\
\end{array}$ & $\begin{array}{l}\frac{0}{0} \\
\frac{0}{n} \\
\end{array}$ & 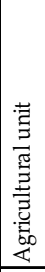 & 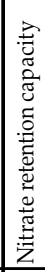 & 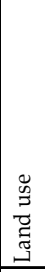 & & 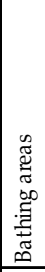 & & 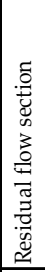 & & 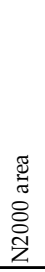 & & 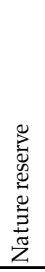 & & 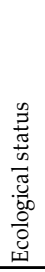 & & 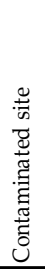 & & 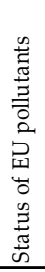 & 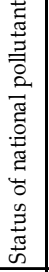 & 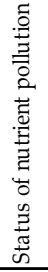 & 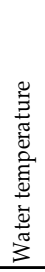 & 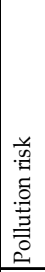 & & 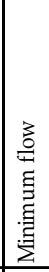 \\
\hline \multirow{29}{*}{ 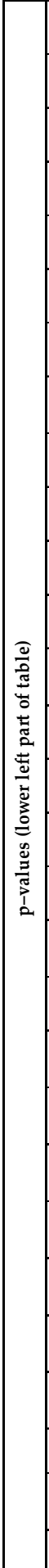 } & Fish region & & \begin{tabular}{l}
$\infty$ \\
\multirow{0}{0}{} \\
$i$ \\
1
\end{tabular} & 䇾 & $\begin{array}{l}0 \\
0 \\
i \\
i\end{array}$ & $\begin{array}{l}\overrightarrow{0} \\
\dot{i}\end{array}$ & $\begin{array}{l}\tilde{i}^{\prime} \\
\bar{i}\end{array}$ & ?: & 旁 & 7. & $\dot{i}$ & o. & $\stackrel{\text { స్ }}{0}$ & $\stackrel{8}{0}$ & 5 & $\stackrel{\infty}{0}$ & ¿̇ & $\stackrel{0}{8}$ & $\stackrel{\substack{0 \\
0}}{0}$ & î & $\overbrace{0}^{\circ}$ & $\stackrel{2}{2}$ & בृ & ? & â. & तે & ถุ & I & o. & 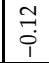 \\
\hline & Glacial river & $\begin{array}{l}8 \\
0 \\
0\end{array}$ & & ֻัণ & $\tilde{\sigma}_{0}^{0}$ & : & $\stackrel{\leftrightarrow}{8}$ & tot & $\begin{array}{l} \\
\dot{i} \\
i\end{array}$ & 8 & 8 & $\begin{array}{l}\overrightarrow{5} \\
i \\
i\end{array}$ & d. & F: & d. & $\begin{array}{l}5 \\
0 \\
0\end{array}$ & $\stackrel{4}{0}$ & $\begin{array}{l}\overrightarrow{5} \\
\dot{i} \\
\end{array}$ & : & $\stackrel{\circ}{\circ}$ & $\overbrace{0}^{8}$ & $\begin{array}{l}\overrightarrow{5} \\
i \\
i\end{array}$ & 巨. & $\begin{array}{l}\overrightarrow{5} \\
i \\
i\end{array}$ & $\begin{array}{l}\overrightarrow{0} \\
\dot{i} \\
\end{array}$ & $\begin{array}{l}\text { a } \\
\dot{0} \\
i\end{array}$ & $\begin{array}{l}7 \\
0 \\
i\end{array}$ & $\begin{array}{l}0 \\
0 \\
i \\
\end{array}$ & $\begin{array}{l}0 \\
0 \\
i \\
\end{array}$ & \begin{tabular}{|ll} 
\\
\\
0 \\
\end{tabular} \\
\hline & Elevation & $\begin{array}{l}8 \\
0 \\
0\end{array}$ & 8 & & $\begin{array}{l}\text { Oे } \\
i \\
\end{array}$ & Oें & 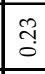 & $\begin{array}{l}7 \\
i \\
\end{array}$ & $\vec{i}$ & $\begin{array}{l}\overrightarrow{5} \\
\dot{1} \\
\end{array}$ & 要 & $\begin{array}{l}0 \\
0 \\
i \\
\end{array}$ & i & 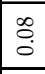 & 9 & $\begin{array}{l}\tilde{O} \\
\dot{i} \\
i\end{array}$ & ?] & $\begin{array}{l}0 \\
\\
0 \\
0\end{array}$ & 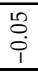 & 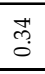 & 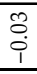 & $\begin{array}{l}\text { t艹 } \\
\text { i } \\
\end{array}$ & 8 & $\begin{array}{l}0 \\
0 \\
0 \\
\end{array}$ & $\begin{array}{l}0 \\
0 \\
i \\
\end{array}$ & \begin{tabular}{l}
\multirow{2}{*}{} \\
$\bar{i}$ \\
\end{tabular} & $\begin{array}{c}\infty \\
0 \\
i \\
i \\
\end{array}$ & \begin{tabular}{|l|l}
$\infty$ \\
0 \\
\end{tabular} & Fi & $\begin{array}{l}\text { o } \\
\dot{i} \\
\end{array}$ \\
\hline & Lake in-/outflow & 8 & : & : & & Fi & $\begin{array}{ll} \\
\\
i \\
i\end{array}$ & $\overline{0}$ & $\overrightarrow{0}$ & $\overbrace{0}^{\infty}$ & $\AA_{0}^{\circ}$ & $\begin{array}{ll} \\
0 \\
0\end{array}$ & $\overbrace{0}^{\circ}$ & $\begin{array}{l}1 \\
0 \\
0 \\
\end{array}$ & $\overbrace{0}^{\circ}$ & $\begin{array}{l}\text { Tे } \\
0 \\
1 \\
\end{array}$ & 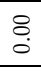 & ช్ & ठ̊. & $\stackrel{\circ}{0}$ & $\overbrace{0}^{\circ}$ & $\stackrel{8}{\circ}$ & ठِ & $\begin{array}{ll} \\
\\
i \\
i\end{array}$ & $\begin{array}{l}\overrightarrow{0} \\
\dot{i}\end{array}$ & $\begin{array}{l}8 \\
0 \\
0 \\
\end{array}$ & $\begin{array}{l}\overline{0} \\
\dot{1} \\
\end{array}$ & $\begin{array}{ll} \\
0 \\
i\end{array}$ & $\stackrel{0}{0}$ & 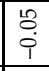 \\
\hline & Geology & 8 & : & $\stackrel{8}{8}$ & : & & Б्: & $\begin{array}{l}\tilde{0} \\
\dot{i}\end{array}$ & $\delta_{0}^{2}$ & $\begin{array}{l}\overrightarrow{0} \\
\dot{i}\end{array}$ & 产 & 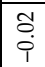 & ì & $\begin{array}{l}\text { ô } \\
\dot{i}\end{array}$ & i & aे & $\overbrace{0}^{0}$ & $\vec{i}$ & ت. & $\begin{array}{l}0 \\
0 \\
i \\
i\end{array}$ & : & $\begin{array}{l}\overrightarrow{0} \\
\dot{i}\end{array}$ & 菅 & 8 & $\overrightarrow{0}_{0}$ & 莫 & 8 & 菅 & $\frac{9}{0}$ & ్ㅗ \\
\hline & Slope & 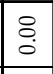 & 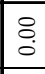 & : & : & : & & : & $\begin{array}{l}0 \\
i \\
i \\
i\end{array}$ & $\begin{array}{l}\text { Tे } \\
\text { i. } \\
\end{array}$ & : & $\begin{array}{l}\overrightarrow{5} \\
i \\
\end{array}$ & $\begin{array}{l}0 \\
0 \\
0\end{array}$ & $\begin{array}{l}20 \\
0 \\
0\end{array}$ & 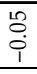 & $\begin{array}{l}\text { ô } \\
\text { i. } \\
\end{array}$ & Oे & $\stackrel{8}{0}$ & 苂 & $\because$ & 8 & $\begin{array}{l}\text { To } \\
\text { i } \\
\end{array}$ & 要 & $\begin{array}{l} \\
0 \\
0 \\
\end{array}$ & 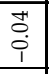 & 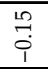 & $\begin{array}{l}\text { ?े } \\
\text { iे } \\
\end{array}$ & $\begin{array}{l}F \\
\\
\end{array}$ & $\begin{array}{l}\text { no } \\
\dot{1} \\
\end{array}$ & $\begin{array}{l}\text { Oे } \\
\text { i } \\
\end{array}$ \\
\hline & Agricultural unit & $\begin{array}{l}8 \\
\end{array}$ & 8 & $\stackrel{8}{0}$ & $\stackrel{8}{0}$ & $\stackrel{8}{0}$ & $\begin{array}{l}8 \\
0 \\
0\end{array}$ & & ô. & $\stackrel{\infty}{0}$ & $\stackrel{\infty}{0}$ & $\stackrel{8}{0}$ & ¿ & $\stackrel{0}{0}$ & : & à & : & ¿े. & 范 & $\begin{array}{l}\text { o̊ } \\
\vdots \\
\end{array}$ & : & 范 & 要 & $\stackrel{8}{\circ}$ & $\overrightarrow{0}_{0}$ & $\begin{array}{l}\overrightarrow{0} \\
\dot{1} \\
\end{array}$ & ${ }_{0}^{\infty}$ & $\begin{array}{ll} \\
0 \\
0 \\
\end{array}$ & $\tilde{0}$ & \begin{tabular}{|l} 
\\
0 \\
0 \\
$i$ \\
\end{tabular} \\
\hline & $\begin{array}{r}\text { Nitrate retention } \\
\text { capacity }\end{array}$ & $\begin{array}{l}8 \\
0 \\
\end{array}$ & : & $\stackrel{8}{0}$ & $\stackrel{8}{\circ}$ & $\stackrel{8}{0}$ & : & $\stackrel{8}{0}$ & & $\stackrel{2}{\circ}$ & $\vec{i}$ & $\stackrel{8}{\circ}$ & $\dot{o}_{0}$ & 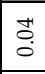 & $\stackrel{2}{0}$ & $\begin{array}{l}0 \\
0 \\
0\end{array}$ & 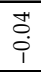 & $\begin{array}{l}\overrightarrow{0} \\
\dot{i} \\
\end{array}$ & : & $\begin{array}{l}\text { o } \\
\dot{i} \\
\end{array}$ & ¿. & $\begin{array}{l}\text { a } \\
0 \\
\end{array}$ & 要 & $\dot{0}_{0}$ & $\overrightarrow{0}$ & $\begin{array}{l}\text { a } \\
\dot{i} \\
\end{array}$ & $\begin{array}{l} \\
\\
0 \\
\end{array}$ & $\begin{array}{l}a \\
0 \\
i\end{array}$ & $\begin{array}{l}0 \\
0 \\
i \\
\end{array}$ & 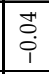 \\
\hline & Land use & $\begin{array}{l}8 \\
0 \\
0\end{array}$ & $\begin{array}{l}8 \\
0 \\
0\end{array}$ & $\stackrel{8}{0}$ & $\begin{array}{l}8 \\
0 \\
0\end{array}$ & $\stackrel{8}{0}$ & $\begin{array}{l}8 \\
0 \\
0\end{array}$ & $\stackrel{8}{\circ}$ & $\begin{array}{l}8 \\
0 \\
0\end{array}$ & & $\stackrel{\grave{i}}{i}$ & $\stackrel{\Delta}{0}$ & $\stackrel{0}{\circ}$ & $\begin{array}{l}\tilde{O} \\
\text { ì } \\
i\end{array}$ & : & $\stackrel{\text { og }}{0}$ & $\stackrel{8}{\circ}$ & $\overbrace{0}^{\circ}$ & $\tilde{o}_{0}$ & $\begin{array}{ll}2 \\
0 \\
i \\
i\end{array}$ & 空 & $\stackrel{0}{\circ}$ & $\stackrel{\infty}{0}$ & $\begin{array}{l}0 \\
0 \\
i \\
1\end{array}$ & $\stackrel{8}{8}$ & $\begin{array}{l}\text { to } \\
\dot{c} \\
\dot{1}\end{array}$ & ?: & \begin{tabular}{ll} 
\\
\multirow{2}{*}{} \\
$i$ \\
$i$
\end{tabular} & $\begin{array}{l}\text { to } \\
\dot{1} \\
\dot{1}\end{array}$ & 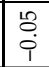 \\
\hline & Forest function & $\begin{array}{l}0 \\
0 \\
\end{array}$ & $\stackrel{8}{0}$ & 8 & $\begin{array}{l}8 \\
0 \\
0\end{array}$ & $\stackrel{\circ}{0}$ & $\begin{array}{l}0 \\
0 \\
0\end{array}$ & $\overbrace{0}^{\circ}$ & 8 & 8 & & 8 & $\Xi_{0}^{\circ}$ & $\stackrel{8}{\circ}$ & ì & o. & ¿े & $\begin{array}{l}0 \\
0 \\
\end{array}$ & $\overbrace{0}^{\circ}$ & $\begin{array}{l} \\
\\
\end{array}$ & ¿ू. & $\begin{array}{l}\overrightarrow{5} \\
i \\
i\end{array}$ & : & $\begin{array}{l}5 \\
0 \\
\end{array}$ & $\begin{array}{l} \\
\dot{i} \\
i\end{array}$ & $\begin{array}{l}\text { to } \\
0 \\
\end{array}$ & $\begin{array}{l}\text { ti } \\
\dot{i} \\
\end{array}$ & \begin{tabular}{|l|l}
0 \\
0 \\
$i$ \\
\end{tabular} & $\begin{array}{l}0 \\
0 \\
i \\
\end{array}$ & ș \\
\hline & Bathing areas & $\begin{array}{l}8 \\
0 \\
0\end{array}$ & : & $\stackrel{8}{8}$ & : & : & $\begin{array}{l}8 \\
0 \\
0\end{array}$ & $\stackrel{8}{8}$ & $\begin{array}{l}8 \\
0 \\
0\end{array}$ & $\stackrel{8}{8}$ & $\overbrace{0}^{\circ}$ & & : & \begin{tabular}{c}
\multirow{2}{*}{} \\
$i$ \\
$i$
\end{tabular} & 尊 & 8 & 菑 & $\tilde{\sigma}_{0}$ & o. & 8 & \&: & $\tilde{\sigma}_{0}$ & : & $\begin{array}{l}0 \\
0 \\
i\end{array}$ & $\begin{array}{l}\overrightarrow{0} \\
\dot{0} \\
i\end{array}$ & $\begin{array}{l}\text { on } \\
\substack{0 \\
i}\end{array}$ & $\begin{array}{ll}\overrightarrow{5} \\
\dot{i} \\
i\end{array}$ & 8 & 产 & $\begin{array}{l}0 \\
0 \\
i \\
i\end{array}$ \\
\hline & Impoundments & $\begin{array}{l}8 \\
0 \\
\end{array}$ & $\stackrel{8}{0}$ & 8 & $\overbrace{0}^{8}$ & 8 & $\overbrace{0}^{\circ}$ & 8 & $\stackrel{8}{0}$ & 8 & $\overbrace{0}^{8}$ & $\stackrel{8}{0}$ & & 8 & 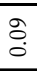 & $\begin{array}{l}\text { in } \\
0 \\
0\end{array}$ & $\stackrel{0}{\circ}$ & $\begin{array}{l}8 \\
0 \\
\end{array}$ & ڤ્a & $\begin{array}{l}\text { a } \\
\dot{0} \\
\end{array}$ & 8 & $\stackrel{8}{8}$ & : & $\begin{array}{ll}\overrightarrow{5} \\
\dot{1}\end{array}$ & $\begin{array}{l}\overrightarrow{5} \\
\dot{i} \\
\end{array}$ & $\begin{array}{ll} \\
\\
\\
\end{array}$ & \begin{tabular}{l}
\multirow{1}{*}{} \\
\\
\end{tabular} & $\begin{array}{l} \\
0 \\
i \\
\end{array}$ & $\begin{array}{l}\text { ti } \\
\dot{i} \\
\end{array}$ & \begin{tabular}{|l} 
\\
\\
\end{tabular} \\
\hline & $\begin{array}{r}\text { Residual flow } \\
\text { section } \\
\end{array}$ & $\begin{array}{l}8 \\
0 \\
\end{array}$ & $0_{0}^{\circ}$ & $\stackrel{8}{\circ}$ & $\stackrel{8}{0}$ & $\stackrel{8}{0}$ & $\stackrel{8}{8}$ & $\stackrel{8}{0}$ & $\begin{array}{l}8 \\
0 \\
\end{array}$ & $\stackrel{8}{0}$ & $\AA_{0}^{\circ}$ & $\stackrel{8}{0}$ & $\AA_{0}^{\circ}$ & & ठ & $\begin{array}{l}\text { ti } \\
\dot{i} \\
\end{array}$ & : & $\begin{array}{l}\text { ô. } \\
\dot{i} \\
\end{array}$ & : & $\begin{array}{l}\infty \\
0 \\
i \\
\end{array}$ & 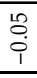 & $\dot{0}$ & $\stackrel{8}{8}$ & 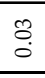 & $\begin{array}{ll}\overrightarrow{5} \\
\dot{i} \\
\end{array}$ & \begin{tabular}{l}
7 \\
\multirow{1}{1}{} \\
\end{tabular} & $\begin{array}{l}\text { Oे } \\
0 \\
i\end{array}$ & $\begin{array}{l}n \\
\\
\end{array}$ & $\begin{array}{l}\text { a } \\
\dot{i} \\
\end{array}$ & 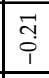 \\
\hline & Flood risk area & $\begin{array}{l}8 \\
0 \\
\end{array}$ & : & : & : & $\begin{array}{l}8 \\
0 \\
0\end{array}$ & : & $\stackrel{8}{0}$ & $\begin{array}{l}8 \\
0 \\
0\end{array}$ & $\stackrel{8}{8}$ & $\stackrel{8}{\circ}$ & $\stackrel{8}{0}$ & : & 8 & & $\begin{array}{l}m \\
0 \\
i\end{array}$ & $\begin{array}{l}8 \\
0 \\
i \\
i\end{array}$ & $\begin{array}{l}\overrightarrow{5} \\
\dot{i} \\
\end{array}$ & $\stackrel{t}{0}$ & $\begin{array}{l}\text { gi } \\
\text { i }\end{array}$ & : & a. & F. & $\begin{array}{l}5 \\
0 \\
i \\
\end{array}$ & $\begin{array}{l}\overrightarrow{0} \\
\dot{T} \\
\end{array}$ & $\begin{array}{l}\infty \\
0 \\
i \\
\end{array}$ & $\begin{array}{ll}0 \\
0 \\
\end{array}$ & $\begin{array}{l}7 \\
i \\
\end{array}$ & $\begin{array}{l}\text { to } \\
\text { i }\end{array}$ & \begin{tabular}{|l}
+ \\
\multirow{1}{*}{} \\
\end{tabular} \\
\hline & N2000 area & $\begin{array}{l}0 \\
0 \\
0\end{array}$ & : & : & : & o & $\stackrel{8}{0}$ & $8_{0}^{\circ}$ & $\begin{array}{l}8 \\
0 \\
0\end{array}$ & $\stackrel{0}{0}$ & $\overbrace{0}^{\circ}$ & 8 & $\AA_{0}^{\circ}$ & 8 & $\frac{8}{8}$ & & İ & ণู่ & $\overbrace{0}^{\infty}$ & $\tilde{O}_{0}^{0}$ & 0 & ô & $\stackrel{8}{8}$ & $\overrightarrow{0}$ & $\overline{0}$ & 菅 & o & 苂 & $\overline{0}$ & $\begin{array}{l}8 \\
0 \\
0\end{array}$ \\
\hline & National park & $\begin{array}{l}8 \\
0 \\
0\end{array}$ & $\stackrel{8}{8}$ & $\begin{array}{l}8 \\
0 \\
0\end{array}$ & $\stackrel{\infty}{0}$ & $\begin{array}{l}8 \\
0 \\
0\end{array}$ & : & $\stackrel{8}{0}$ & $\begin{array}{l}8 \\
0 \\
0\end{array}$ & $\stackrel{8}{0}$ & $\stackrel{8}{0}$ & $\stackrel{8}{0}$ & \&. & $\stackrel{8}{8}$ & \&. & $\stackrel{8}{0}$ & & 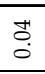 & ¿. & בี & : & $\begin{array}{l}\overrightarrow{5} \\
\dot{i} \\
\end{array}$ & 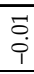 & $\begin{array}{l}\overrightarrow{5} \\
\dot{0} \\
\end{array}$ & $\begin{array}{l}\overrightarrow{5} \\
\dot{T} \\
\end{array}$ & $\begin{array}{l}\text { to } \\
0 \\
\end{array}$ & $\begin{array}{l}0 \\
0 \\
0 \\
\end{array}$ & $\begin{array}{l}\text { 总 } \\
0 \\
\end{array}$ & $\begin{array}{l}0 \\
0 \\
0 \\
\end{array}$ & $\begin{array}{l}\overrightarrow{5} \\
\dot{0} \\
\end{array}$ \\
\hline & \begin{tabular}{|l} 
Nature reserve \\
\end{tabular} & $\begin{array}{l}8 \\
0 \\
0\end{array}$ & $\overbrace{0}^{\circ}$ & 8 & $\begin{array}{l}8 \\
0 \\
0\end{array}$ & 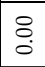 & f & 8 & $\begin{array}{l}8 \\
0 \\
0\end{array}$ & $\overbrace{0}^{\circ}$ & 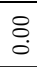 & 8 & 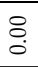 & $\begin{array}{l}8 \\
8 \\
0\end{array}$ & : & 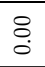 & $e_{0}^{\circ}$ & & 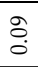 & gे & $\overbrace{0}^{\infty}$ & $\overrightarrow{\vec{c}}$ & : & $\overrightarrow{0}$ & $\begin{array}{ll}\overrightarrow{0} \\
\dot{i} \\
\end{array}$ & $\begin{array}{ll}0 \\
0 \\
i\end{array}$ & $\begin{array}{ll} & 0 \\
0 \\
i \\
i\end{array}$ & $\begin{array}{ll} & \\
0 \\
i\end{array}$ & $\begin{array}{l}\text { mo } \\
\dot{0} \\
i\end{array}$ & \begin{tabular}{|l|l} 
\\
$\dot{0}$ \\
$i$
\end{tabular} \\
\hline & $\begin{array}{r}\begin{array}{r}\text { Water protection } \\
\text { area }\end{array} \\
\end{array}$ & $\begin{array}{l}8 \\
0 \\
0\end{array}$ & $\begin{array}{l}8 \\
0 \\
0\end{array}$ & $\stackrel{8}{0}$ & $\begin{array}{l}8 \\
0 \\
0\end{array}$ & $\stackrel{8}{0}$ & $\begin{array}{l}8 \\
0 \\
0\end{array}$ & 8 & $\begin{array}{l}8 \\
0 \\
0\end{array}$ & $\stackrel{8}{0}$ & $\stackrel{8}{\circ}$ & $\stackrel{0}{0}$ & $\stackrel{8}{\circ}$ & $\stackrel{0}{0}$ & 8 & $\stackrel{8}{0}$ & : & $\stackrel{8}{0}$ & & s. & $\tilde{D}_{0}$ & $\stackrel{8}{\circ}$ & ${ }_{0}^{0}$ & $\stackrel{\delta}{0}$ & $\begin{array}{l}\overrightarrow{0} \\
\dot{i} \\
\end{array}$ & $\tilde{o}_{0}$ & $\stackrel{8}{\circ}$ & $\begin{array}{l}0 \\
\vdots \\
i\end{array}$ & $\stackrel{8}{0}$ & $\stackrel{\substack{0 \\
i \\
i}}{i}$ \\
\hline & Ecological status & $\begin{array}{l}8 \\
0 \\
0\end{array}$ & $\stackrel{8}{\circ}$ & $\stackrel{8}{0}$ & $\begin{array}{l}8 \\
0 \\
0\end{array}$ & $\stackrel{8}{\circ}$ & $\begin{array}{l}8 \\
0 \\
0\end{array}$ & $\stackrel{8}{\circ}$ & $\begin{array}{l}8 \\
0 \\
0\end{array}$ & $\stackrel{8}{0}$ & : & : & : & 奋 & $\stackrel{8}{0}$ & $\stackrel{8}{0}$ & ${ }_{0}^{\circ}$ & $\stackrel{8}{0}$ & : & & ?. & $\begin{array}{l}0 \\
0 \\
i \\
i\end{array}$ & î & $\begin{array}{l}2 \\
0 \\
i \\
i\end{array}$ & $\begin{array}{l}\text { og } \\
\dot{1} \\
\end{array}$ & 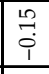 & 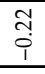 & 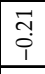 & $\begin{array}{l}\overline{0} \\
\dot{i} \\
i\end{array}$ & $\ddot{i}$ \\
\hline & $\begin{array}{r}\begin{array}{r}\text { Valuable river } \\
\text { sections }\end{array}\end{array}$ & $\begin{array}{l}8 \\
0 \\
0\end{array}$ & $\stackrel{\infty}{\infty}$ & 8. & $\stackrel{8}{8}$ & : & 我 & $\stackrel{8}{8}$ & \& & $\stackrel{8}{8}$ & : & $\stackrel{8}{\circ}$ & : & $\stackrel{8}{8}$ & : & $\stackrel{8}{8}$ & : & $\stackrel{8}{8}$ & : & $\stackrel{8}{8}$ & & Õ & du & $\stackrel{\substack{0 \\
i \\
i}}{i}$ & $\stackrel{0}{0}$ & 菅 & $\stackrel{\circ}{\circ}$ & $\stackrel{n}{0}$ & $\begin{array}{l}\text { ồ } \\
\text { i }\end{array}$ & 盛 \\
\hline & $\begin{array}{r}\text { Contaminated } \\
\text { site }\end{array}$ & $\begin{array}{l}8 \\
0 \\
0\end{array}$ & : & $\stackrel{0}{\circ}$ & $\stackrel{8}{\circ}$ & $\stackrel{8}{\circ}$ & : & $\stackrel{\circ}{\circ}$ & $\begin{array}{l}8 \\
0 \\
0\end{array}$ & $\stackrel{\circ}{\circ}$ & : & $\stackrel{0}{\circ}$ & : & $\stackrel{\circ}{\circ}$ & : & $\stackrel{\circ}{\circ}$ & 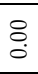 & $\stackrel{8}{\circ}$ & $\stackrel{8}{0}$ & $\stackrel{0}{\circ}$ & 8 & & $\stackrel{n}{0}$ & $\stackrel{8}{\circ}$ & $\stackrel{0}{0}$ & $\stackrel{8}{0}$ & $\stackrel{\circ}{\circ}$ & $\begin{array}{l}\overrightarrow{0} \\
i \\
\end{array}$ & $\begin{array}{l}\text { ș } \\
\text { i }\end{array}$ & $\begin{array}{l}\tilde{O} \\
\dot{i} \\
i\end{array}$ \\
\hline & $\begin{array}{r}\text { Emission } \\
\text { discharge } \\
\end{array}$ & $\begin{array}{l}8 \\
0 \\
\end{array}$ & 8 & $\begin{array}{l}8 \\
0 \\
0\end{array}$ & 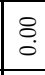 & $\stackrel{8}{0}$ & 8 & 8 & $\begin{array}{l}8 \\
0 \\
0\end{array}$ & 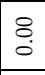 & $\stackrel{8}{\circ}$ & $\stackrel{8}{0}$ & $\stackrel{8}{\circ}$ & 8 & $\circ$ & $\stackrel{8}{0}$ & : & $\stackrel{8}{0}$ & $\stackrel{8}{0}$ & $\stackrel{8}{\circ}$ & $\stackrel{8}{\circ}$ & $\stackrel{8}{\circ}$ & & 菅 & $\begin{array}{l}0 \\
0 \\
0\end{array}$ & $\begin{array}{l}\overrightarrow{0} \\
i \\
\end{array}$ & in & \begin{tabular}{|l|l}
0 \\
0 \\
1 \\
\end{tabular} & $\begin{array}{l}\text { ô. } \\
\text { i. } \\
\end{array}$ & $\begin{array}{l}0 \\
\overline{1} \\
\end{array}$ \\
\hline & $\begin{array}{r}\text { Status of EU } \\
\text { pollutants }\end{array}$ & $\begin{array}{l} \\
0 \\
\end{array}$ & 8 & $\AA_{0}^{\circ}$ & $\begin{array}{l}8 \\
0 \\
0\end{array}$ & $\stackrel{8}{0}$ & : & $\stackrel{8}{0}$ & $\begin{array}{l}8 \\
0 \\
0\end{array}$ & $\stackrel{8}{0}$ & : & $\stackrel{8}{0}$ & : & $\stackrel{8}{\circ}$ & : & $\stackrel{8}{\circ}$ & : & $\stackrel{8}{\circ}$ & : & $\stackrel{8}{\circ}$ & : & : & $\stackrel{8}{8}$ & & $\stackrel{\infty}{0}$ & $\stackrel{8}{\circ}$ & gे & Iี & $\begin{array}{l}\text { ô. } \\
\text { i }\end{array}$ & $\begin{array}{ll} \\
\\
i\end{array}$ \\
\hline & $\begin{array}{r}\begin{array}{l}\text { Status of national } \\
\text { pollutants }\end{array} \\
\text {. }\end{array}$ & $\begin{array}{l}8 \\
0 \\
\end{array}$ & 8 & $\stackrel{8}{0}$ & $\begin{array}{l}8 \\
0 \\
0\end{array}$ & $\stackrel{8}{8}$ & $\begin{array}{l}8 \\
0 \\
0\end{array}$ & $\stackrel{8}{\circ}$ & $\begin{array}{l}8 \\
0 \\
0\end{array}$ & : & $\stackrel{8}{0}$ & 8 & \& & $\stackrel{8}{8}$ & 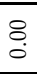 & $\stackrel{8}{\circ}$ & $\stackrel{8}{\circ}$ & $\stackrel{8}{\circ}$ & $\stackrel{8}{\circ}$ & $\stackrel{8}{\circ}$ & 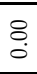 & $\stackrel{0}{0}$ & $\stackrel{8}{\circ}$ & : & & $\stackrel{9}{0}$ & : & $\stackrel{9}{0}$ & $\begin{array}{l}\overrightarrow{0} \\
\dot{i}\end{array}$ & 8 \\
\hline & $\begin{array}{r}\text { Status of nutrient } \\
\text { pollution }\end{array}$ & $\begin{array}{l}0 \\
0 \\
\end{array}$ & : & $\AA_{0}^{\circ}$ & : & $\stackrel{8}{0}$ & ¿ & $\stackrel{8}{0}$ & : & $\stackrel{0}{0}$ & $\stackrel{8}{\circ}$ & $\stackrel{8}{0}$ & : & $\stackrel{0}{0}$ & $\stackrel{8}{\circ}$ & $\stackrel{0}{0}$ & $\stackrel{8}{0}$ & $\overbrace{0}^{\circ}$ & $\stackrel{8}{0}$ & $\stackrel{0}{0}$ & $\stackrel{8}{\circ}$ & : & : & $\AA_{0}^{\circ}$ & $\stackrel{8}{0}$ & & בิ่ & $\begin{array}{l}\infty \\
\stackrel{2}{0} \\
0\end{array}$ & के & $\stackrel{\infty}{\circ}$ \\
\hline & $\begin{array}{r}\text { Water } \\
\text { temperature }\end{array}$ & $\begin{array}{l}8 \\
0 \\
\end{array}$ & 8 & $0_{0}^{\circ}$ & $\stackrel{8}{0}$ & $\stackrel{8}{0}$ & $\stackrel{8}{0}$ & $\stackrel{0}{0}$ & $\stackrel{8}{0}$ & $\stackrel{8}{0}$ & : & $\stackrel{8}{0}$ & : & $\stackrel{8}{0}$ & 8 & $\stackrel{8}{0}$ & 8 & $\stackrel{0}{0}$ & $\stackrel{8}{0}$ & $\stackrel{8}{0}$ & $\stackrel{8}{0}$ & $\stackrel{8}{0}$ & 8 & $\stackrel{8}{0}$ & $\stackrel{0}{0}$ & $\stackrel{8}{0}$ & & $\stackrel{\infty}{0}$ & $\stackrel{2}{0}$ & $\begin{array}{l}9 \\
9 \\
\end{array}$ \\
\hline & Pollution risk & $\begin{array}{l}8 \\
0 \\
\end{array}$ & $\begin{array}{l}8 \\
0 \\
\end{array}$ & $\begin{array}{l}8 \\
0 \\
\end{array}$ & $\begin{array}{l}8 \\
0 \\
\end{array}$ & $\begin{array}{l}8 \\
0 \\
0\end{array}$ & \begin{tabular}{|l}
8 \\
8 \\
\end{tabular} & $\begin{array}{l}8 \\
8 \\
\end{array}$ & \begin{tabular}{|l}
8 \\
8 \\
\end{tabular} & $\begin{array}{l}8 \\
8 \\
0\end{array}$ & 8 & $\begin{array}{l}8 \\
0 \\
\end{array}$ & 8 & $\begin{array}{l}8 \\
8 \\
\end{array}$ & 8 & 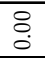 & 8 & 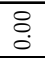 & $\begin{array}{l}8 \\
\\
0\end{array}$ & $\begin{array}{l}8 \\
8 \\
0\end{array}$ & 8 & 8 & 8 & $\begin{array}{l}8 \\
0 \\
\end{array}$ & 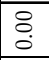 & $\begin{array}{l}8 \\
0 \\
\end{array}$ & $\begin{array}{l}8 \\
0 \\
0\end{array}$ & & 둥 & लَ \\
\hline & $\begin{array}{r}\text { Summer low } \\
\text { flow } \\
\end{array}$ & $\begin{array}{l}8 \\
0 \\
\end{array}$ & $\stackrel{8}{0}$ & $\stackrel{8}{0}$ & $\begin{array}{l}\tilde{O} \\
0 \\
\end{array}$ & $\stackrel{8}{0}$ & $\begin{array}{l}8 \\
8 \\
\end{array}$ & $\begin{array}{l}8 \\
0 \\
\end{array}$ & $\begin{array}{l}8 \\
8 \\
\end{array}$ & $\begin{array}{l}8 \\
0 \\
\end{array}$ & $\stackrel{0}{0}$ & 8 & $\stackrel{0}{0}$ & 8 & ${ }^{\circ}$ & $\stackrel{8}{0}$ & 0 & $\stackrel{8}{0}$ & $\ddot{\circ}$ & $\begin{array}{l}8 \\
0 \\
\end{array}$ & : & $\begin{array}{l}8 \\
0 \\
\end{array}$ & : & $\begin{array}{l}8 \\
0 \\
\end{array}$ & 8 & $\begin{array}{l}8 \\
0 \\
\end{array}$ & $\stackrel{8}{0}$ & 8 & & $\begin{array}{l}+ \\
\\
0\end{array}$ \\
\hline & Minimum flow & \begin{tabular}{|l|} 
\\
8 \\
0
\end{tabular} & \begin{tabular}{|l|l}
8 \\
0 \\
0
\end{tabular} & $\begin{array}{l}8 \\
0 \\
0\end{array}$ & $\begin{array}{ll}8 \\
8 \\
0\end{array}$ & $\begin{array}{ll}8 \\
0 \\
0\end{array}$ & $\begin{array}{l}8 \\
8 \\
0\end{array}$ & \begin{tabular}{|l|l}
8 \\
0 \\
0
\end{tabular} & $\begin{array}{ll}8 \\
8 \\
0\end{array}$ & $\begin{array}{ll}8 \\
0 \\
0\end{array}$ & & \begin{tabular}{|l|l}
8 \\
0 \\
\end{tabular} & & \begin{tabular}{|l|l}
8 \\
0 \\
\end{tabular} & & $\begin{array}{l}! \\
\\
\end{array}$ & & $\begin{array}{l}8 \\
8 \\
0\end{array}$ & & 8 & & $\begin{array}{l}8 \\
8 \\
\end{array}$ & & $\begin{array}{l}8 \\
8 \\
\end{array}$ & 8 & \begin{tabular}{|l}
8 \\
0 \\
\end{tabular} & $\begin{array}{l}8 \\
0 \\
0\end{array}$ & $\begin{array}{ll}8 \\
0 \\
0\end{array}$ & $\begin{array}{l}8 \\
8 \\
\end{array}$ & \\
\hline
\end{tabular}




\section{References}

1. FAO. The State of the World Fisheries and Aquaculture 2020-Sustainability in Action; FAO: Rome, Italy, 2020. [CrossRef]

2. FAO. The State of the World Fisheries and Aquaculture 2016 - Contributing to Food Security and Nutrition for All; FAO: Rome, Italy, 2016.

3. Merino, G.; Barange, M.; Blanchard, J.L.; Harle, J.; Holmes, R.; Allen, I.; Allison, E.H.; Badjeck, M.C.; Dulvy, N.K.; Holt, J.; et al. Can marine fisheries and aquaculture meet fish demand from a growing human population in a changing climate? Glob. Environ. Chang. 2012, 22, 795-806. [CrossRef]

4. FAO. The State of World Fisheries and Aquaculture 2018-Meeting the Sustainable Development Goals; FAO: Rome, Italy, 2018.

5. EUMOFA. The EU Fish Market, 2020 Edition; Publication Office of the European Union: Brussels, Belgium, 2020. [CrossRef]

6. BMLFUW. Aquakultur 2020-Österreichische Strategie zur Förderung der Nationalen Fischproduktion; Bundesministerium für Landund Forstwirtschaft, Umwelt und Wasserwirtschaft: Vienna, Austria, 2012.

7. Statistik Austria. Supply Balance for Fish 2014 to 2019 in Tonnes. Available online: http://www.statistik.at/web_de/statistiken/ wirtschaft/land_und_forstwirtschaft/preise_bilanzen/versorgungsbilanzen/022380.html (accessed on 13 November 2020).

8. FAO. Code of Conduct for Responsible Fisheries; FAO: Rome, Italy, 1995.

9. FAO. Aquaculture Development. 4. Ecosystem Approach to Aquaculture; FAO: Rome, Italy, 2010; Volume 5.

10. Brugère, C.; Aguilar-Manjarrez, J.; Beveridge, M.C.M.; Soto, D. The ecosystem approach to aquaculture 10 years on-A critical review and consideration of its future role in blue growth. Rev. Aquac. 2018, 1-22. [CrossRef]

11. Soto, D.; Aguilar-Manjarrez, J.; Brugère, C.; Angel, D.; Bailey, C.; Black, K.; Edwards, P.; Costa-Pierce, B.; Chopin, T.; Deudero, S.; et al. Applying an ecosystem-based approach to aquaculture: Principles, scales and some management measures. FAO Fish Aquac. Proc. 2008, 14, 15-35. [CrossRef]

12. European Commission. Communication from the Commission to the European Parliament, the Council, The Economic and Social Committee and the Committee of the Regions-Our Life Insurance, Our Natural Capital: An EU Biodiversity Strategy to 2020; SEC(2011) 540 final; SEC: Brussels, Belgium, 2011. [CrossRef]

13. FAO. Blue Growth Initiative -Partnering with Countries to Achieve the Sustainable Development Goals; FAO: Rome, Italy, 2017.

14. Aguilar-Manjarrez, J.; Soto, D.; Brummett, R. Aquaculture Zoning, Site Selection and Area Management under the Ecosystem Approach to Aquaculture; FAO: Rome, Italy, 2017.

15. European Commission. Roadmap-Farm to Fork. 2020. Available online: https://ec.europa.eu/info/law/better-regulation/ have-your-say/initiatives/12183-Farm-to-Fork-Strategy (accessed on 27 December 2020).

16. European Commission. From Farm to Fork-The European Green Deal. 2019. Available online: https://ec.europa.eu/info/ strategy / priorities-2019-2024/european-green-deal/actions-being-taken-eu/farm-fork_en (accessed on 27 December 2020).

17. Yin, S.; Takeshige, A.; Miyake, Y.; Kimura, S. Selection of suitable coastal aquaculture sites using Multi-Criteria Decision Analysis in Menai Strait, UK. Ocean Coast Manag. 2018, 165, 268-279. [CrossRef]

18. FAO. Aquaculture Zoning, Site Selection and Area Management under the Ecosystem Approach to Aquaculture. Policy Brief; FAO: Rome, Italy, 2015; p. 4.

19. European Commission. Directive 2000/60/EC of the European Parliament and of the Council of 23 October 2000 Establishing a Framework for Community Action in the Field of Water Policy; European Commission: Brussels, Belgium, 2000; p. 71.

20. European Commission. Council Directive 92/43/EEC of 21 May 1992 on the Conservation of Natural Habitats and of Wild Fauna and Flora; European Commission: Brussels, Belgium, 1992; p. 44. [CrossRef]

21. European Commission. Directive 2007/60/EC of the European Council and European Parliament of 23 October 2007 on the Assessment and Management of Flood Risks; European Commission: Brussels, Belgium, 2007.

22. European Commission. Directive 2009/147/EC of the European Parliament and of the Council of 30 November 2009 on the Conservation of Wild Birds; European Commission: Brussels, Belgium, 2009.

23. FAO. The Water-Energy-Food Nexus. A New Approach in Support of Food Security and Sustainable Agriculture; FAO: Rome, Italy, 2014; pp. 1-28. [CrossRef]

24. Aguilar-Manjarrez, J.; McDaid Kapetsky, J.; Soto, D. The Potential of Spatial Planning Tools to Support the Ecosystem Approach to Aquaculture; FAO: Rome, Italy, 2010.

25. Ross, L.G.; Telfer, T.C.; Falconer, L.; Soto, D.; Aguilar-Manjarrez, J.; Asmah, R.; Bermúdez, J.; Beveridge, M.C.M.; Byron, C.J.; Clément, A.; et al. Carrying capacities and site selection within the ecosystem approach to aquaculture. FAO Fish Aquac. Proc. 2013, 21, 19-46.

26. Francisco, H.R.; Corrêia, A.F.; Feiden, A. Classification of areas suitable for fish farming using geotechnology and multi-criteria analysis. ISPRS Int. J. Geo-Inf. 2019, 8, 394. [CrossRef]

27. Malczewski, J. On the use of weighted linear combination method in GIS: Common and best practice approaches. Trans. GIS 2000, 4, 5-22. [CrossRef]

28. Falconer, L.; Middelboe, A.L.; Kaas, H.; Ross, L.G.; Telfer, T.C. Use of geographic information systems for aquaculture and recommendations for development of spatial tools. Rev. Aquac. 2019, 1-14. [CrossRef]

29. Longley, P.A.; Goodchild, M.F.; Maguire, D.J.; Rhind, D.W. Geographic Information Science and Systems, 4th ed.; Wiley: Hoboken, NJ, USA, 2015

30. Kane, F.; Jackson, D.; Casserly, J. A critical review of the existing aquaculture licensing and regulatory frameworks in the EU. In Proceedings of the Aquaculture Europe 2017, Dubrovnik, Croatia, 17-20 October 2017. 
31. BMLFUW. Nationaler Gewässerbewirtschaftungsplan 2015; Bundesministerium für Land- und Forstwirtschaft, Umwelt und Wasserwirtschaft: Vienna, Austria, 2017.

32. Auer, I.; Böhm, R.; Mohnl, H.; Potzmann, R.; Schöner, W.; Skomorowski, P.Ö. Digitaler Klimaatlas Österreichs. Eine interaktive Reise durch die Vergangenheit, Gegenwart und Zukunft des Klimas. In Die Zentralanstalt für Meteorol. und Geodyn. $1851-2001$. 150 Jahre Meteorol. und Geophys; Hammerl, C., Lenhardt, W., Steinacker, R., Steinhauser, P., Eds.; Leykam: Graz, Austria, 2001. Available online: https:/ /www.zamg.ac.at/cms/de/klima/klimaforschung/klimatografien/oeklim-196120131990 (accessed on 13 December 2020).

33. BMLFUW. Hydrologischer Atlas Österreich, Bundesministerium für Land-und Forstwirtschaft, Umwelt und Wasserwirtschaft, Abteilung Wasserhaushalt (HZB), 3rd ed.; 2007. Available online: https://www.bmlrt.gv.at/wasser/wasser-oesterreich/ wasserkreislauf/hydrologischer_atlas.html (accessed on 29 January 2021).

34. Yunis, C.R.C.; López, R.S.; Cruz, S.M.O.; Castillo, E.B.; López, J.O.S.; Trigoso, D.I.; Briceño, N.B.R. Land suitability for sustainable aquaculture of rainbow trout (Oncorhynchus mykiss) in Molinopampa (Peru) based on RS, GIS, and AHP. ISPRS Int. J. Geo-Inf. 2020, 9, 28. [CrossRef]

35. Ssegane, H.; Tollner, E.W.; Veverica, K. Geospatial Modeling of Site Suitability for Pond-Based Tilapia and Clarias Farming in Uganda. J. Appl. Aquac. 2012, 24, 147-169. [CrossRef]

36. Assefa, W.W.; Abebe, W.B. GIS modeling of potentially suitable sites for aquaculture development in the Lake Tana basin, Northwest Ethiopia. Agric. Food Secur. 2018, 7, 1-15. [CrossRef]

37. Falconer, L.; Telfer, T.C.; Ross, L.G. Investigation of a novel approach for aquaculture site selection. J. Environ. Manag. 2016, 181, 791-804. [CrossRef] [PubMed]

38. Mcleod, I.; Pantus, F.; Preston, N. The use of a geographical information system for land-based aquaculture planning. Aquac. Res. 2002, 33, 231-250. [CrossRef]

39. Salam, M.A.; Khatun, N.A.; Ali, M.M. Carp farming potential in Barhatta Upazilla, Bangladesh: A GIS methodological perspective. Aquaculture 2005, 245, 75-87. [CrossRef]

40. Mustafa, F.B.; Bwadi, B.E. Determination of Optimal Freshwater Prawn Farming Site Locations using GIS and Multicriteria Evaluation. J. Coast Res. 2018, 82, 41-54. [CrossRef]

41. Völcker, C.M.; Scott, P. SIG e sensoriamento remoto para a determinação do potencial para aqüicultura no baixo São João-RJ. Revista Eletrônica Sistemas Gestão 2008, 3, 196-215. [CrossRef]

42. Kumar, R.S.; Bahadur, G.T.; Prasad, L.G. GIS Based Evaluation on Potential Sites of Cold Water Fish, Rainbow Trout (Oncorhynchus Mykiss) Farming in NUWAKOT, Nepal; Bahadur, G.T., Ed.; Fisheries Research Division, Godawari, Lalitpur of NARC: Kathmandu, Nepal, 2008; pp. 103-108.

43. Díaz, I.; Mello, A.L.; Salhi, M.; Spinetti, M.; Bessonart, M.; Achkar, M. Multiscalar land suitability assessment for aquaculture production in Uruguay. Aquac. Res. 2017, 48, 3052-3065. [CrossRef]

44. Kapetsky, J.M.; Nath, S.S. A Strategic Assessment of the Potential for Freshwater Fish Farming in Latin America; FAO: Rome, Italy, 1997.

45. Aryal, S.P.; Paudel, M.N. GIS Based Potentiality of Rainbow Trout (Oncorhynchus Mykiss) Farming in Northern High Hill Rasuwa, Nepal. Proc. 1st Natl. Work. Scaling-Up Rainbow Trout (Onchorhynchus Mykiss) Farming Strateg; Fisheries Research Division, Godawari, Lalitpur of NARC: Kathmandu, Nepal, 2008; p. 158. [CrossRef]

46. Taseli, B.K. Response of lake water quality to wastewater inputs from land-based fish farm located on Yuvarlakçay Creek in Köycegiz-Dalyan Specially Protected Area, Turkey. Environ. Monit. Assess. 2009, 157, 557-574. [CrossRef]

47. Von Lukowicz, M. Site selection and regulation issues for trout and carp farming in Germany. J. Appl. Ichthyol. 1994, 10, 312-318. [CrossRef]

48. Eastman, J.R. IDRISI Selva Tutorial. Idrisi Prod. Clark Univ. 2012, 45, 51-63.

49. Schinegger, R. Vorschläge zur Abgrenzung des potentiellen Fischlebensraums in alpinen Fließgewässern. Master's Thesis, University of Natural Resources and Life Sciences, Vienna, Austria, 2006.

50. Mills, D. Salmon and Trout: A Resource, It's Ecology, Conservation and Management; St. Martin's Press: New York, NY, USA, 1971.

51. Illies, J. Versuch einer allgemeinen biozönotischen Gliederung der Fließgewässer. Int. Rev. Ges. Hydrobiol. Hydrogr. 1961, 46, 205-213. [CrossRef]

52. Haunschmid, R.; Wolfram, G.; Spindler, T.; Honsig-Erlenburg, W.; Wimmer, R.; Jagsch, A.; Kainz, E.; Hohenwarter, K.; Wagner, B.; Konecny, R.; et al. Erstellung einer fischbasierten Typologie Österreichischer Fließgewässer sowie einer Bewertungsmethode des fischökologischen Zustandes gemäß EU-Wasserrahmenrichtlinie. Bundesamt Wasserwirtschaft 2006.

53. Haßlacher, P.; Langegger, C. Österreichisches Gletscherbachinventar; Österreichischer Alpenverein: Innsbruck, Austria, 1988.

54. Füreder, L.; Vacha, C. Fließgewässertypisierung im Nationalpark Hohe Tauern. Wiss. Mitt. Aus. Dem. Natl. Hohe Tauern. 2001, 6, 191-209.

55. Zick, D.; Gassner, H.; Filzmoser, P.; Wanzenböck, J.; Pamminger-Lahnsteiner, B.; Tischler, G. Changes in the fish species composition of all Austrian lakes $>50$ ha during the last 150 years. Fish Manag. Ecol. 2006, 13, 103-111. [CrossRef]

56. Gafner, K.; Meyer, M. Brown trouts in the Canton of Bern-Migration corridors and monitoring. WasserWirtschaft 2018, $108,14-17$. [CrossRef]

57. Copernicus. Coperenicus (clc2018) 2018. Available online: https://land.copernicus.eu/pan-european/corine-land-cover/clc2018 (accessed on 13 April 2019). 
58. Forstgesetz. BGBl. Nr. 440/1975. Bundesgesetz vom 3. Juli 1975, mit dem das Forstwesen Geregelt Wird. 1975. Available online: https: / / www.ris.bka.gv.at/GeltendeFassung.wxe?Abfrage=Bundesnormen\&Gesetzesnummer=10010371 (accessed on 29 January 2021).

59. BMLRT. Waldentwicklungsplan 2018. Available online: https://www.waldentwicklungsplan.at/ (accessed on 15 May 2019 ).

60. BFW. Waldkarte. Bundesforschungszentrum für Wald, Naturgefahren und Landschaft 2018. Available online: https://bfw.ac.at/ rz/bfwcms.web?dok=7222 (accessed on 1 December 2020).

61. AMA. AgrarMarkt Austria-Integriertes Verwaltung-und Kontrollsystem (Invekos); AMA: Chicago, IL, USA, 2018.

62. BMLFUW. BGBl. II Nr. 100/2015. Horizontale GAP Verordnung. 2015. Available online: https://www.ris.bka.gv.at/ GeltendeFassung.wxe?Abfrage=Bundesnormen\&Gesetzesnummer=20009149 (accessed on 29 January 2021).

63. Murer, E. Abschätzung des Rückhaltevermögens der landwirtschaftlich genutzten Böden Österreichs. Schriftenr BAW 2003, 19, 70-79.

64. Wasserrechtsgesetz. BGBl. Nr. 215/1959. 1959. Available online: https://www.ris.bka.gv.at/GeltendeFassung.wxe?Abfrage= Bundesnormen\&Gesetzesnummer=10010290 (accessed on 29 January 2021).

65. BMLFUW. Qualitätszielverordnung Ökologie Oberflächengewässer-QZVO Ökologie OG (CELEX-Nr.: 32000L0060). Bundesministerium für Land- und Forstwirtschaft, Umwelt und Wasserwirtschaft. 2010. Available online: https://www.ris.bka.gv.at/ GeltendeFassung.wxe?Abfrage=Bundesnormen\&Gesetzesnummer=20006736 (accessed on 15 May 2020).

66. BGBl. Nr. 299/1989. Bundesgesetz vom 7. Juni 1989 zur Finanzierung und Durchführung der Altlastensanierung (Altlastensanierungsgesetz). 1989. Available online: https://www.ris.bka.gv.at/GeltendeFassung.wxe?Abfrage=Bundesnormen\& Gesetzesnummer=10010583 (accessed on 17 August 2020).

67. Elliott, J.M. Some Aspects of Thermal Stress on Freshwater Teleosts; Academic Press: London, UK, 1981.

68. Humpesch, U.H. Inter- and intra-specific variation in hatching success and embryonic development of five species of salmonids and Thymallus thymallus. Arch. Für Hydrobiol. 1985, 104, 129-144.

69. Jungwirth, M.; Winkler, H. The temperature dependence of embryonic development of grayling (Thymallus thymallus), Danube salmon (Hucho hucho), arctic charr (Salvelinus alpinus) and brown trout (Salmo trutta fario). Aquaculture 1984, 38, 315-327. [CrossRef]

70. Elliott, J.M.; Elliott, J.A.; Allonby, J.D. The critical thermal limits for the stone loach, Noemacheilus barbatulus, from 3 populations in North-West England. Freshw. Biol. 1994, 32, 593-601. [CrossRef]

71. Jungwirth, M.; Haidvogl, G.; Moog, O.; Muhar, S.; Schmutz, S. Angewandte Fischökologie an Fließgewässern; Facultas: Wien, Austria, 2003; Volume 53. [CrossRef]

72. Borgwardt, F.; Unfer, G.; Auer, S.; Waldner, K.; El-Matbouli, M.; Bechter, T. Direct and Indirect Climate Change Impacts on Brown Trout in Central Europe: How Thermal Regimes Reinforce Physiological Stress and Support the Emergence of Diseases. Front. Environ. Sci. 2020, 8, 59. [CrossRef]

73. Therneau, T.M.; Atkinson, E.J. An Introduction to Recursive Partitioning Using the RPART Routines; Mayo Foundation: Rochester, MN, USA, 2019. [CrossRef]

74. Breiman, L.; Friedman, J.; Stone, C.J. Classificatoin and Regression Trees; Chapman and Hall/CRC: Boca Raton, FL, USA, 1984.

75. Buck, B.H.; Langan, R. Aquaculture perspective of multi-use sites in the open ocean: The untapped potential for marine resources in the anthropocene. In Aquaculture Perspective of Multi-Use Sites in the Open Ocean; Springer: Cham, Switzerland, 2017. [CrossRef]

76. Bricker, S.B.; Getchis, T.L.; Chadwick, C.B.; Rose, C.M.; Rose, J.M. Integration of ecosystem-based models into an existing interactive web-based tool for improved aquaculture decision-making. Aquaculture 2016, 453, 135-146. [CrossRef]

77. Gimpel, A.; Stelzenmüller, V.; Töpsch, S.; Galparsoro, I.; Gubbins, M.; Miller, D.; Murillas, A.; Murray, A.G.; Pınarbaşı, K.; Roca, G.; et al. A GIS-based tool for an integrated assessment of spatial planning trade-offs with aquaculture. Sci. Total Environ. 2018, 627, 1644-1655. [CrossRef] [PubMed]

78. Gomes Ferreira, R.; Ferreira, J.G.; Boogert, F.J.; Corner, R.A.; Nunes, J.P.; Grant, J.; Johansen, J.; Dewey, W.F. A multimetric investor index for aquaculture: Application to the European Union and Norway. Aquaculture 2020, 516, 734600. [CrossRef]

79. Vianna, L.F.d.N.; Filho, J.B. Spatial analysis for site selection in marine aquaculture: An ecosystem approach applied to Baía Sul, Santa Catarina, Brazil. Aquaculture 2018, 489, 162-174. [CrossRef]

80. Nayak, A.K.; Kumar, P.; Pant, D.; Mohanty, R.K. Land suitability modelling for enhancing fishery resource development in Central Himalayas (India) using GIS and multi-criteria evaluation approach. Aquac. Eng. 2018, 83, 120-129. [CrossRef]

81. Hao, T.; Elith, J.; Guillera-Arroita, G.; Lahoz-Monfort, J.J. A review of evidence about use and performance of species distribution modelling ensembles like BIOMOD. Divers Distrib. 2019, 25, 839-852. [CrossRef]

82. Schmidt, H.; Radinger, J.; Stoll, S.; Teschlade, D. The role of spatial units in modelling freshwater fish distributions: Comparing a subcatchment and river network approach using MaxEnt. Ecol. Model. 2020, 418, 108937. [CrossRef]

83. Schinegger, R.; Pucher, M.; Aschauer, C.; Schmutz, S. Configuration of multiple human stressors and their impacts on fish assemblages in Alpine river basins of Austria. Sci. Total Environ. 2018, 616-617, 17-28. [CrossRef] 
84. Hadipour, A.; Vafaie, F.; Hadipour, V. Land suitability evaluation for brackish water aquaculture development in coastal area of Hormozgan, Iran. Aquac. Int. 2014, 23, 329-343. [CrossRef]

85. SAEPEA. A Sustainable Food System for the European Union. Science Advice for Policy by Eropean Academies. Evid. Rev. Rep. 2020, 7, 221. [CrossRef] 